\title{
Os Cientistas na Toponímia de LisboA*
}

\section{Isabel Cipriano ${ }^{1}$, João Paulo Leal ${ }^{2}$}

\begin{abstract}
Ser cidadão consciente, participativo e possuidor de cultura científica, passa, também, pela capacidade de olhar para uma placa toponímica e conseguir ler para além do nome do homenageado, ou seja, identificar a pessoa que viveu numa determinada época, desenvolveu várias actividades, nomeadamente a científica, e reconhecer que a ciência se foi construindo, ao longo dos tempos, por pessoas que tiveram e que continuam eventualmente a ter a sua importância na vida da nossa sociedade.
\end{abstract}

\section{Conceitos de Ciência e Cientista}

A definição do conceito de cientista surgiu como necessidade primordial para o desenvolvimento deste trabaIho. Santo Agostinho referindo-se ao tempo, afirmava: "O que é, por conseguinte, o tempo? Se ninguém mo perguntar, eu sei; se o quiser explicar a quem me fizer a pergunta, já não sei". Será que todos nós não fomos já uma vez por outra cientistas? Quando sentimos aquela curiosidade natural de uma criança, que nos leva a interrogar, a pesquisar e a procurar compreender o que nos rodeia? Ou será que um cientista é alguém que se dedica inteira e exclusivamente ao trabalho de pesquisa e, além disso, domina um conhecimento específico e incompreensível para o cidadão comum?

Cabe aqui referir algumas perspectivas do conceito de Ciência, começando por aquela que diz que Ciência (da palavra latina scientia, que significa conhecimento), em sentido amplo, é o conhecimento ou saber e em sentido restrito é o conjunto de conhecimentos sobre a natureza, a sociedade, o pensamento, adquiridos através de um determinado método [1]. Outra perspectiva é considerar a Ciência como um dos pontos centrais de reflexão filosófica. Os parâmetros pelos

\footnotetext{
Baseado numa tese de Mestrado apresentada na Faculdade de Ciências da Universidade de Lisboa.

1 Escola Secundária de Pedro Alexandrino, Rua Aquilino Ribeiro, 2620-182 Póvoa de Santo Adrião, Portugal 2 Unidade de Ciências Químicas e Radiofarmacêuticas, Instituto Tecnológico e Nuclear, 2686-953 Sacavém, Faculdade de Ciências, Universidade de Lisboa, 1749-016 Lisboa, Portugal E-mail: jpleal@itn.pt
}

quais esta reflexão se orienta têm mudado ao longo dos tempos, fruto, em parte, da própria evolução da Ciência [2], criando-se a epistemologia, cuja tarefa fundamental é pensar a Ciência, o que ela é e como se faz, valor do seu conhecimento e quais os seus fundamentos [3].

A Ciência é um meio de evitar preconceitos na solução de problemas. É a observação precisa de coisas que acontecem, a interrogação de problemas adequados, o avançar de respostas possíveis, o teste controlado destas respostas e a dedução de conclusões apropriadas dos resultados dos testes. A função da Ciência é fornecer meios para a resolução de problemas e alcançar conclusões que são, tanto quanto possível, livres de interesse e preconceitos [4].

Segundo Gilberto Câmara [5] a Ciência opera de duas formas básicas: por descoberta e por invenção. Newton descobriu a lei da gravitação universal e Edison inventou a luz eléctrica. Pode ainda tomar uma terceira forma: a da construção de artefactos formais de expressão do pensamento. Há mesmo quem ache que "É melhor desistir. Nunca chegaremos a definir o que é Ciência... Qualquer tentativa para o fazer, que abranja a história do Homem, cairá por terra. Porque não existe acordo entre os homens de diferentes gerações, nem de uma mesma geração, e porque, não esqueçamos, a evolução e a revolução são situações que a Ciência acolhe sistematicamente. Mas todos estamos de acordo que o conhecimento do mundo externo, ordenado e sistematizado, descrito e compreendido, e as ferramentas para tal conseguir fazem parte do mundo científico" [6].

A "Declaração sobre Ciência e a utilização do conhecimento científico" adoptada pela Conferência Mundial sobre "Ciência para o Século XXI: Um Novo Compromisso", realizada em Budapeste em 1999, sob a égide da Organização das Nações Unidas para a Educação, Ciência e Cultura (UNESCO) e do Conselho Internacional da Ciência (ICSU) considerou que no século $X X I$ a Ciência tem de se tornar um bem partilhado, beneficiando todos os povos numa base de solidariedade, que a Ciência é um poderoso recurso para a compreensão de fenómenos naturais e sociais, e que o seu papel promete ser ainda maior no futuro, à medida que a crescente complexidade do relacionamento entre a sociedade e o ambiente é melhor compreendida. Assim, a função inerente ao trabalho científico é desenvolver uma investigação sistemática e aprofundada da natureza e da sociedade, que conduza a novos conhecimentos [7].

Após a primeira década do século XVII, o método científico de comparar hipóteses com experiências e observação para separar o trigo do joio tinha sido claramente expresso no trabalho de Gilbert (1544-1603), em Inglaterra, e Galileu Galilei (1564-1642), na Itália. Mas não podemos esquecer os feitos dos antigos gregos, dos chineses e dos filósofos islâmicos que tanto fizeram para manter viva a busca pelo conhecimento sobre o nosso mundo durante o período que os europeus 
referem como idade das Trevas ou Idade Média [8].

O trabalho de um cientista pode ser mais intelectual ou mais experimental, mas é racional. Muitos cientistas passam o seu tempo em trabalho de campo, outros a construir bases de dados a partir da observação experimental, outros ainda, os teóricos, a interpretar dados ou modelos. Cientista é a pessoa que se dedica às ciências, a uma em particular ou à investigação científica [1]. É alguém "que tem a capacidade de examinar problemas de diferentes perspectivas e procurar explicações dos fenómenos naturais e sociais, submetendo-as constantemente a análise crítica" [7].

O conceito de cientista utilizado neste estudo é resultado de todas as referências anteriormente citadas. Cientista é aquele que quer conhecer e compreender o desconhecido, saber sempre mais, para transformar e optimizar o que o rodeia, utilizando um método adequado para poder chegar à verdade. Apesar de aparentemente simples, sabe-se que acção de classificar implica sempre situações no limite da definição, sendo a decisão de inclusão ou exclusão motivo de discussão e de alguma subjectividade. Como tal, outras pessoas, noutro estudo, poderiam ter por opção incluir nomes aqui não considerados ou excluir alguns aqui citados.

\section{A TOPONÍMIA dE LISBOA}

Toponímia, vocábulo composto por dois étimos gregos, cujo significado aponta para a incontornável necessidade humana de designar qualquer lugar (topos) pelo seu nome (onyma). A existência de pontos de referência, para orientação e localização, foi sempre uma necessidade do Homem. Quando se tratava de pequenos povoados, bastava fazer referência ao local de uma festa religiosa ou de uma feira, a uma igreja, a uma casa de uma personalidade ilustre ou popular, assim como a referência a um monte, a um vale ou a uma árvore, mas quando as urbes cresceram foi necessário criar um outro sistema de referência dentro da cidade.
A designação dos arruamentos de Lisboa teve sempre um carácter pragmático, destinando-se essencialmente a criar pontos de referência para orientação dentro da cidade. O primeiro diploma que tratou exclusivamente de matéria toponímica foi a Portaria de 5 de Novembro de 1760, na qual D. José estabelece a nomenclatura dos arruamentos entre a Praça do Comércio e a Praça do Rossio. Em 1800 surgiu a necessidade de organizar um serviço eficaz de correios e a paralela organização de polícia, o que fez surgir regras de identificação de casas e de ruas. De 1836 a 1878 competia ao Governo Civil de Lisboa a denominação das vias públicas. Só em 1878, com o Código Administrativo, se entrega à Câmara Municipal a competência para tomar decisões a nível da toponímia. Em 1910 as sessões da Câmara referem uma Comissão "para a nomenclatura das Ruas". No entanto, só em 1940 o Código Administrativo definiu de forma clara as competências da Câmara nesta matéria sendo em 1943 criada a Comissão Municipal de Toponímia [9].

O uso de antropónimos teve carácter de excepção até ao século XVIII, salientando-se que em 1466, como homenagem de memória, o povo denominou espontaneamente um arruamento de grande importância, Rua D'El Rei, ou Rua Nova D'El Rei, referindo-se a quem a mandou construir, D. Afonso V. A homenagem intencional (1760) surge com a denominação das principais ruas de Lisboa reconstruída: Rua Nova D’El Rei, Rua Bela da Rainha, Rua Nova da Princesa e Rua do Príncipe. As atribuições oficiais ocorreram em 1836, com a denominação da Rua e Praça D. Pedro IV, em homenagem ao Rei Soldado, então erigido Herói Nacional [10].

A toponímia revela "saber" porque revela cultura e conhecimento. Dá vida a personalidades, não as deixando cair no esquecimento, mas também é retrato da ideologia dominante no país, das ideias que orientam as atribuições nas diversas épocas históricas. Paula Machado indica, no seu estudo "Os estrangeiros vistos nas ruas de Lisboa", seis épocas, com diferente número de anos, mas agrupadas pelo mesmo tempo ideológico do poder instituído [11]. Assim considera:

- 1876 a 1909 - (Monarquia), desde que o Código Administrativo consagrou o direito de denominação das ruas e lugares públicos à Câmara Municipal;

- 1910 a 1926 - (I República), porque apesar da $1^{a}$ vereação republicana datar de 1908, a reorganização republicana da edilidade só se efectuou após a implantação da República;

- 1927 a 1973 - (II República - Ditadura Militar e Estado Novo), quando os membros da edilidade eram nomeados pelo Governo e a Comissão Municipal de Toponímia, criada em 1942, era composta por personalidades nomeadas pelo Presidente da Câmara;

- 1974 a 1979 - (Democracia), englobando as sucessivas Comissões Administrativas de Abril de 1974 a 1976, e o mandato presidido por Aquilino Ribeiro Machado, de 1977 a 1979, época em que a Comissão de Toponímia teve também sucessivos presidentes e era composta por 3 representantes da Câmara, nomeados pelo Presidente;

- 1980 a 1989 - com uma Comissão de Toponímia composta por 3 representantes da Câmara, nomeados pelo Presidente;

- 1990 a 1997 - quando a composição da Comissão Municipal de toponímia foi alargada, pelo Edital $n^{\circ}$ 48/90 de 4 de Junho: para além dos representantes da Câmara - vereador do Pelouro competente, Departamento do Património Cultural e Gabinete de Estudos Olisiponenses - a instituições da cidade - as 3 Universidades de Lisboa, a Sociedade Portuguesa de Autores e 2 Cidadãos de reconhecido mérito, um dos quais indicado pelo Grupo Amigos de Lisboa.

A partir do último período referido até à presente data houve várias Comissões de Toponímia, que respeitaram sempre a representatividade das instituições da cidade. A actual Comissão de Toponímia, de acordo com o Despacho $n^{\circ} 235 / P / 06$, nomeada para o período 2006-2009, é constituída pelo Presidente e por 12 Vogais: 9 em representação da Direcção Municipal de Cultura, da Direcção Municipal de 
Gestão Urbanística, do Departamento de Serviços Gerais, do Gabinete de Estudos Olisiponenses, da Universidade de Lisboa, da Universidade Técnica de Lisboa, da Universidade Nova de Lisboa, da Sociedade Portuguesa de Autores, do Grupo dos Amigos de Lisboa e 3 cidadãos de reconhecido mérito pelos seus conhecimentos e estudos sobre a cidade de Lisboa.

Também as linhas orientadoras para atribuição dos topónimos foram variando ao longo dos tempos. Por exemplo, na I República aparece expressa a intenção de homenagear individualidades entre as quais cientistas: "Dar preferência a individualidades que se tivessem notabilizado no campo das ciências, das artes, das letras ou que tenham prestado relevante serviço à Pátria ou à Cidade de Lisboa " [12]. No entanto, durante a I República e o Estado Novo ocorreu a politização da Toponímia numa tentativa de muitas vezes re-escrever a História. A revolução de 25 de Abril de 1974 trouxe uma mudança gradual de mentalidades. Contudo, só em 1990, a nova composição da Comissão de Toponímia com carácter interdisciplinar contribuiu para a representatividade das diferentes áreas do conhecimento. Actualmente a Comissão Municipal de Toponímia tem como finalidade essencial a denominação de novos arruamentos ou a alteração dos já existentes, através da elaboração de pareceres. No entanto, esta Comissão, consciente da importância dos topónimos já existentes para a memória da cidade, pretende preservá-los. Selecciona as propostas feitas por qualquer cidadão ou entidade e escolhe o local mais adequado para atribuição do mesmo. Depois, a Comissão ausculta a respectiva Junta de Freguesia e delibera. No caso do parecer ser favorável, é agendado para Reunião de Câmara para aprovação final.

\section{Os Cientistas na Toponímia DE LISBOA}

O concelho de Lisboa está dividido em 53 freguesias, sendo o número exacto de arruamentos difícil de conhecer, pois depende do critério utilizado na sua contagem. Pode contar-se por topónimo ou por arruamento com to- pónimos oficiais. A contagem por topónimo deixaria de fora muitos arruamentos. Considere-se o exemplo do topónimo Santo António para o qual existem 23 arruamentos associados [13]. A contagem por topónimos oficiais exclui os topónimos não oficiais, as vilas, pátios, jardins, azinhagas, quintas, casais, miradouros, bairros. A sua inclusão na contagem [14] pode levar a um acréscimo de cerca de 2000 arruamentos. Contudo, os topónimos não oficiais na sua maioria são muito antigos, não sendo usuais os antropónimos, pelo que se considerará o número de 4038 arruamentos com topónimos oficiais [15]. Este valor é aproximado, pois a Cidade de Lisboa está em transformação e em crescimento, o que pode levar ao desaparecimento de alguns arruamentos e ao surgimento de muitos outros.

Não foi possível obter na base de dados da CMT-CML (Comissão Municipal de Toponímia da $\mathrm{CML}$ ) o número de arruamentos com antropónimos. Este número foi obtido por contagem feita a partir dos dados da Corvusbase - Base de Dados de Toponímia, actualizada até 2006 e ascende a 1535 antropónimos na toponímia de Lisboa [16].

Seguindo para a definição de cientista nas linhas gerais definidas anteriormente sobre o que é um cientista, foi possível encontrar 144 cientistas homenageados na toponímia de Lisboa, 143 homens e 1 mulher (Tabela 1).

\begin{tabular}{|c|c|c|}
\hline $\begin{array}{l}\text { Abade José } \\
\text { Custódio de } \\
\text { Faria }\end{array}$ & Goa 1746 & $\begin{array}{l}\text { Paris } \\
1819\end{array}$ \\
\hline $\begin{array}{l}\text { Abel de Lima } \\
\text { Salazar }\end{array}$ & $\begin{array}{c}\text { Guimarães } \\
1889\end{array}$ & $\begin{array}{l}\text { Lisboa } \\
1946 \\
\end{array}$ \\
\hline $\begin{array}{c}\text { Achilles Alfredo } \\
\text { da Silveira } \\
\text { Machado }\end{array}$ & $\begin{array}{l}\text { Queluz } \\
1862\end{array}$ & $\begin{array}{l}\text { Lisboa } \\
1942\end{array}$ \\
\hline $\begin{array}{l}\text { Agostinho } \\
\text { Vicente } \\
\text { Lourenço }\end{array}$ & Goa 1822 & $\begin{array}{l}\text { Lisboa } \\
1893\end{array}$ \\
\hline $\begin{array}{l}\text { Alberto } \\
\text { Macbride } \\
\text { Fernandes }\end{array}$ & Lisboa 1886 & $\begin{array}{l}\text { Lisboa } \\
1953\end{array}$ \\
\hline $\begin{array}{l}\text { Alberto Santos } \\
\text { Dumont }\end{array}$ & $\begin{array}{c}\text { Minas Gerais } \\
1873\end{array}$ & $\begin{array}{c}\text { Guarujá } \\
1932\end{array}$ \\
\hline $\begin{array}{l}\text { Alexandre } \\
\text { Fleming }\end{array}$ & $\begin{array}{c}\text { Lochfield } \\
1881 \\
\end{array}$ & $\begin{array}{c}\text { Londres } \\
1955 \\
\end{array}$ \\
\hline $\begin{array}{c}\text { Alexandre } \\
\text { Gustave Eiffel }\end{array}$ & Dijon 1832 & $\begin{array}{l}\text { Paris } \\
1923 \\
\end{array}$ \\
\hline $\begin{array}{l}\text { Alfredo Schiappa } \\
\text { Monteiro de } \\
\text { Carvalho }\end{array}$ & 1838 & 1919 \\
\hline
\end{tabular}

\begin{tabular}{|c|c|c|}
\hline $\begin{array}{l}\text { Alfredo } \\
\text { Bensaúde }\end{array}$ & $\begin{array}{c}\text { Ponta } \\
\text { Delgada } \\
1856\end{array}$ & $\begin{array}{c}\text { Ponta } \\
\text { Delgada } \\
1941\end{array}$ \\
\hline Alfredo Franco & $\begin{array}{c}\text { Guarda } \\
1909\end{array}$ & $\begin{array}{l}\text { Lisboa } \\
1993\end{array}$ \\
\hline $\begin{array}{l}\text { Almerindo } \\
\text { Vasconcelos } \\
\text { Lessa }\end{array}$ & Porto 1909 & $\begin{array}{l}\text { Lisboa } \\
1995\end{array}$ \\
\hline $\begin{array}{l}\text { Aníbal de } \\
\text { Bettencourt }\end{array}$ & $\begin{array}{c}\text { Angra do } \\
\text { Heroísmo } \\
1868\end{array}$ & $\begin{array}{l}\text { Lisboa } \\
1930\end{array}$ \\
\hline $\begin{array}{c}\text { António Artur } \\
\text { Baldaque da } \\
\text { Silva }\end{array}$ & Lisboa 1852 & $\begin{array}{l}\text { Lisboa } \\
1915\end{array}$ \\
\hline $\begin{array}{l}\text { António } \\
\text { Augusto de } \\
\text { Aguiar }\end{array}$ & Lisboa 1838 & $\begin{array}{l}\text { Lisboa } \\
1887\end{array}$ \\
\hline $\begin{array}{l}\text { António } \\
\text { Caetano de } \\
\text { Abreu Freire } \\
\text { Egas Moniz }\end{array}$ & $\begin{array}{c}\text { Avanca } \\
1874\end{array}$ & $\begin{array}{l}\text { Lisboa } \\
1955\end{array}$ \\
\hline $\begin{array}{l}\text { António dos } \\
\text { Santos Lucas }\end{array}$ & $\begin{array}{c}\text { Gouveia } \\
1866\end{array}$ & $\begin{array}{c}\text { Guarda } \\
1939\end{array}$ \\
\hline $\begin{array}{c}\text { António Ferreira } \\
\text { da Silva }\end{array}$ & $\begin{array}{c}\text { Couto de } \\
\text { Cucujões } \\
1853\end{array}$ & $\begin{array}{c}\text { Santiago } \\
\text { de Riba } \\
1923\end{array}$ \\
\hline $\begin{array}{c}\text { António } \\
\text { Gedeão } \\
\text { pseudónimo de } \\
\text { Rómulo Vasco } \\
\text { da Gama de } \\
\text { Carvalho }\end{array}$ & Lisboa 1906 & $\begin{array}{l}\text { Lisboa } \\
1997\end{array}$ \\
\hline $\begin{array}{l}\text { António Nunes } \\
\text { Ribeiro Sanches }\end{array}$ & $\begin{array}{c}\text { Penamacor } \\
1699\end{array}$ & $\begin{array}{l}\text { Paris } \\
1783\end{array}$ \\
\hline $\begin{array}{c}\text { António Pedro } \\
\text { da Costa } \\
\text { Malheiro }\end{array}$ & Lisboa 1933 & $\begin{array}{l}\text { Lisboa } \\
1998\end{array}$ \\
\hline $\begin{array}{l}\text { António Pereira } \\
\text { Sousa Câmara }\end{array}$ & Lisboa 1901 & $\begin{array}{c}\text { Lisboa } \\
1984 \\
\end{array}$ \\
\hline $\begin{array}{l}\text { António Xavier } \\
\text { Correia Barreto }\end{array}$ & Lisboa 1853 & $\begin{array}{c}\text { Lisboa } \\
1939 \\
\end{array}$ \\
\hline $\begin{array}{l}\text { Arnaldo de } \\
\text { Carvalho } \\
\text { Sampaio }\end{array}$ & Lisboa 1908 & $\begin{array}{l}\text { Lisboa } \\
1984\end{array}$ \\
\hline $\begin{array}{c}\text { Arsénio Luís } \\
\text { Rebelo Alves } \\
\text { Cordeiro }\end{array}$ & Lisboa 1910 & $\begin{array}{l}\text { Lisboa } \\
1982\end{array}$ \\
\hline $\begin{array}{c}\text { Mário Moura } \\
\text { Brás Arsénio } \\
\text { Nunes }\end{array}$ & 1919 & $\begin{array}{l}\text { Lisboa } \\
1977\end{array}$ \\
\hline $\begin{array}{l}\text { Artur Sacadura } \\
\text { Freire Cabral }\end{array}$ & $\begin{array}{l}\text { Celorico da } \\
\text { Beira } 1881\end{array}$ & $\begin{array}{c}\text { Mar do } \\
\text { Norte } \\
1924\end{array}$ \\
\hline $\begin{array}{c}\text { Augusto Pires } \\
\text { Celestino da } \\
\text { Costa }\end{array}$ & Lisboa 1884 & $\begin{array}{l}\text { Lisboa } \\
1956\end{array}$ \\
\hline $\begin{array}{c}\text { Aureliano } \\
\text { Lopes de Mira } \\
\text { Fernandes }\end{array}$ & $\begin{array}{c}\text { Mértola } \\
1884\end{array}$ & $\begin{array}{l}\text { Lisboa } \\
1958\end{array}$ \\
\hline $\begin{array}{c}\text { Ayres Francisco } \\
\text { Nicéforo de } \\
\text { Sousa } \\
\end{array}$ & $\begin{array}{l}\text { Goa } \\
1905\end{array}$ & $\begin{array}{l}\text { Lisboa } \\
1980\end{array}$ \\
\hline $\begin{array}{l}\text { Bartolomeu } \\
\text { Lourenço de } \\
\text { Gusmão }\end{array}$ & $\begin{array}{r}\text { Brasil } \\
1685\end{array}$ & $\begin{array}{l}\text { Toledo } \\
1724\end{array}$ \\
\hline $\begin{array}{l}\text { Benjamin } \\
\text { Franklin }\end{array}$ & $\begin{array}{c}\text { Boston } \\
1706\end{array}$ & $\begin{array}{c}\text { Filadélfia } \\
1790\end{array}$ \\
\hline $\begin{array}{c}\text { Bento de Jesus } \\
\text { Caraça }\end{array}$ & $\begin{array}{c}\text { Vila Viçosa } \\
1901\end{array}$ & $\begin{array}{c}\text { Lisboa } \\
1948 \\
\end{array}$ \\
\hline $\begin{array}{c}\text { Bernardino } \\
\text { António Gomes } \\
\text { (pai) }\end{array}$ & $\begin{array}{c}\text { Paredes } \\
1768\end{array}$ & $\begin{array}{l}\text { Lisboa } \\
1823\end{array}$ \\
\hline $\begin{array}{c}\text { Caetano } \\
\text { António C. J. R. } \\
\text { da Gama Pinto }\end{array}$ & $\begin{array}{l}\text { Goa } \\
1853\end{array}$ & $\begin{array}{l}\text { Lisboa } \\
1945\end{array}$ \\
\hline $\begin{array}{c}\text { Carlos Alberto } \\
\text { Viegas Gago } \\
\text { Coutinho }\end{array}$ & Lisboa 1869 & $\begin{array}{l}\text { Lisboa } \\
1959\end{array}$ \\
\hline $\begin{array}{c}\text { Carlos Karoly } \\
\text { Mardell }\end{array}$ & $\begin{array}{l}\text { Hungria } \\
\text { c. } 1695\end{array}$ & $\begin{array}{l}\text { Lisboa } \\
1763\end{array}$ \\
\hline
\end{tabular}




\begin{tabular}{|c|c|c|}
\hline Carlos Ribeiro & Lisboa 1813 & $\begin{array}{l}\text { Lisboa } \\
1882\end{array}$ \\
\hline $\begin{array}{l}\text { Carlos Salazar } \\
\text { de Sousa }\end{array}$ & Lisboa 1904 & $\begin{array}{l}\text { Lisboa } \\
1980\end{array}$ \\
\hline Carlos Teixeira & $\begin{array}{l}\text { Aboim } \\
1910\end{array}$ & $\begin{array}{l}\text { Lisboa } \\
1982\end{array}$ \\
\hline $\begin{array}{c}\text { César Augusto } \\
\text { Campos } \\
\text { Rodrigues }\end{array}$ & Lisboa 1836 & $\begin{array}{l}\text { Lisboa } \\
1919\end{array}$ \\
\hline $\begin{array}{c}\text { Conde de } \\
\text { Ficalho } \\
\text { Francisco } \\
\text { Manuel de } \\
\text { Mello Breyner }\end{array}$ & $\begin{array}{l}\text { Lisboa } \\
1837\end{array}$ & $\begin{array}{l}\text { Lisboa } \\
1920\end{array}$ \\
\hline $\begin{array}{c}\text { Constantino } \\
\text { Álvaro Sobral } \\
\text { Fernandes }\end{array}$ & Lisboa 1878 & $\begin{array}{l}\text { Lisboa } \\
1920\end{array}$ \\
\hline Custódio Vieira & Séc. XVIII & \\
\hline $\begin{array}{c}\text { Dom João de } \\
\text { Castro }\end{array}$ & 1500 & 1548 \\
\hline $\begin{array}{c}\text { Duarte Pacheco } \\
\text { Pereira }\end{array}$ & $\begin{array}{l}\text { Lisboa } \\
\text { c. } 1460 \\
\end{array}$ & $\begin{array}{c}\text { Lisboa } \\
1533 \\
\end{array}$ \\
\hline $\begin{array}{c}\text { Edgar António } \\
\text { de Mesquita } \\
\text { Cardoso }\end{array}$ & $\begin{array}{l}\text { Porto } \\
1913\end{array}$ & $\begin{array}{l}\text { Lisboa } \\
2000\end{array}$ \\
\hline $\begin{array}{c}\text { Edmundo Lima } \\
\text { Basto }\end{array}$ & Lisboa 1911 & $\begin{array}{c}\text { Lisboa } \\
1971 \\
\end{array}$ \\
\hline $\begin{array}{c}\text { Eduardo } \\
\text { Arantes e } \\
\text { Oliveira } \\
\end{array}$ & $\begin{array}{l}\text { Tomar } \\
1907\end{array}$ & $\begin{array}{l}\text { Lisboa } \\
1982\end{array}$ \\
\hline $\begin{array}{c}\text { Eduardo } \\
\text { Carneiro de } \\
\text { Araújo Coelho }\end{array}$ & $\begin{array}{c}\text { Santo Tirso } \\
1896\end{array}$ & $\begin{array}{l}\text { Lisboa } \\
1974\end{array}$ \\
\hline $\begin{array}{c}\text { Eduardo Luís } \\
\text { O'Connor } \\
\text { Fhirley Zuzarte } \\
\text { Cortesão } \\
\end{array}$ & 1919 & 1991 \\
\hline $\begin{array}{l}\text { Ernesto Galião } \\
\text { Roma }\end{array}$ & $\begin{array}{c}\text { Viana do } \\
\text { Castelo } \\
1887 \\
\end{array}$ & $\begin{array}{l}\text { Lisboa } \\
1978\end{array}$ \\
\hline $\begin{array}{l}\text { Ernesto Júlio } \\
\text { de Carvalho e } \\
\text { Vasconcelos }\end{array}$ & $\begin{array}{l}\text { Almeirim } \\
1852\end{array}$ & $\begin{array}{l}\text { Lisboa } \\
1930\end{array}$ \\
\hline $\begin{array}{l}\text { Eugénio } \\
\text { dos Santos } \\
\text { Carvalho }\end{array}$ & $\begin{array}{c}\text { Aliubarrota } \\
1711\end{array}$ & $\begin{array}{l}\text { Lisboa } \\
1760\end{array}$ \\
\hline $\begin{array}{c}\text { Eurico Sidónio } \\
\text { Gouveia Xavier } \\
\text { Lopes da } \\
\text { Fonseca }\end{array}$ & Lisboa 1921 & $\begin{array}{l}\text { Lisboa } \\
2000\end{array}$ \\
\hline $\begin{array}{c}\text { Fausto Lopo } \\
\text { Patrício de } \\
\text { Carvalho }\end{array}$ & $\begin{array}{c}\text { Guarda } \\
1890\end{array}$ & $\begin{array}{l}\text { Lisboa } \\
1970\end{array}$ \\
\hline $\begin{array}{c}\text { Félix da Silva de } \\
\text { Avelar Brotero }\end{array}$ & $\begin{array}{c}\text { Sto Antão do } \\
\text { Tojal } 1744\end{array}$ & $\begin{array}{c}\text { Lisboa } \\
1828 \\
\end{array}$ \\
\hline $\begin{array}{c}\text { Fernando da } \\
\text { Conceição } \\
\text { Fonseca }\end{array}$ & Lisboa 1895 & $\begin{array}{l}\text { Lisboa } \\
1974\end{array}$ \\
\hline Filipe Folque & $\begin{array}{c}\text { Portalegre } \\
1800 \\
\end{array}$ & $\begin{array}{l}\text { Lisboa } \\
1874 \\
\end{array}$ \\
\hline $\begin{array}{c}\text { Filipe Henriques } \\
\text { Vaz } \\
\end{array}$ & Lisboa 1912 & $\begin{array}{c}\text { Lisboa } \\
1994 \\
\end{array}$ \\
\hline $\begin{array}{c}\text { Francisco } \\
\text { da Fonseca } \\
\text { Benevides } \\
\end{array}$ & Lisboa 1835 & $\begin{array}{l}\text { Lisboa } \\
1911\end{array}$ \\
\hline $\begin{array}{c}\text { Francisco Gentil } \\
\text { Martins }\end{array}$ & Lisboa 1927 & $\begin{array}{c}\text { Lisboa } \\
1988 \\
\end{array}$ \\
\hline $\begin{array}{c}\text { Francisco } \\
\text { Gomes Teixeira }\end{array}$ & $\begin{array}{c}\text { S. Cosmado } \\
\text { Armamar } \\
1851\end{array}$ & $\begin{array}{l}\text { Porto } \\
1933\end{array}$ \\
\hline $\begin{array}{c}\text { Francisco Luís } \\
\text { Pereira de Sousa }\end{array}$ & $\begin{array}{c}\text { Funchal } \\
1870\end{array}$ & $\begin{array}{c}\text { Portimão } \\
1931\end{array}$ \\
\hline $\begin{array}{c}\text { Francisco Pulido } \\
\text { Valente }\end{array}$ & Lisboa 1884 & $\begin{array}{c}\text { Lisboa } \\
1963 \\
\end{array}$ \\
\hline $\begin{array}{l}\text { Francisco } \\
\text { Sanches }\end{array}$ & $\begin{array}{l}\text { Diocese de } \\
\text { Braga } 1550 \\
\text { ou } 1551\end{array}$ & $\begin{array}{c}\text { Toulouse } \\
1623\end{array}$ \\
\hline $\begin{array}{c}\text { Francisco Soares } \\
\text { Branco Gentil }\end{array}$ & $\begin{array}{l}\text { Alcácer do } \\
\text { Sal } 1878\end{array}$ & $\begin{array}{l}\text { Lisboa } \\
1964\end{array}$ \\
\hline
\end{tabular}

\begin{tabular}{|c|c|c|}
\hline $\begin{array}{c}\text { Francisco Xavier } \\
\text { da Silva Teles }\end{array}$ & $\begin{array}{c}\text { Pondá, Goa } \\
1860\end{array}$ & $\begin{array}{c}\text { Lisboa } \\
1930\end{array}$ \\
\hline $\begin{array}{l}\text { Garcia Abraão } \\
\text { de Orta }\end{array}$ & $\begin{array}{c}\text { Castelo de } \\
\text { Vide c. } 1499\end{array}$ & $\begin{array}{l}\text { Goa } \\
1568\end{array}$ \\
\hline $\begin{array}{c}\text { Georges } \\
\text { Zbyszewski }\end{array}$ & $\begin{array}{c}\text { Gatchina, } \\
\text { Rússia } 1909\end{array}$ & $\begin{array}{c}\text { Lisboa } \\
1999 \\
\end{array}$ \\
\hline $\begin{array}{l}\text { Guglielmo } \\
\text { Marconi }\end{array}$ & $\begin{array}{c}\text { Bolonha } \\
1874\end{array}$ & $\begin{array}{l}\text { Roma } \\
1937\end{array}$ \\
\hline $\begin{array}{l}\text { Henrique da } \\
\text { Costa Maya }\end{array}$ & Lisboa 1917 & $\begin{array}{c}\text { Lisboa } \\
1988 \\
\end{array}$ \\
\hline $\begin{array}{l}\text { Henrique Jardim } \\
\text { de Vilhena }\end{array}$ & Lisboa 1879 & $\begin{array}{l}\text { Lisboa } \\
1958\end{array}$ \\
\hline $\begin{array}{c}\text { Henrique João } \\
\text { Barahona } \\
\text { Fernandes }\end{array}$ & $\begin{array}{l}\text { Vinhais } \\
1907\end{array}$ & $\begin{array}{l}\text { Lisboa } \\
1992\end{array}$ \\
\hline $\begin{array}{l}\text { Ildefonso } \\
\text { Borges }\end{array}$ & $\begin{array}{c}\text { Santa Cruz } \\
\text { da Graciosa } \\
1864\end{array}$ & $\begin{array}{l}\text { Lisboa } \\
1942\end{array}$ \\
\hline Isaac Newton & $\begin{array}{c}\text { Woolsthorpe } \\
1642 \\
\end{array}$ & $\begin{array}{c}\text { Kensington } \\
1727 \\
\end{array}$ \\
\hline $\begin{array}{l}\text { João Afonso } \\
\text { Cid dos Santos }\end{array}$ & Lisboa 1907 & $\begin{array}{c}\text { Lisboa } \\
1975 \\
\end{array}$ \\
\hline $\begin{array}{c}\text { João Alberło } \\
\text { Pereira } \\
\text { Azevedo Neves }\end{array}$ & $\begin{array}{c}\text { Angra do } \\
\text { Heroísmo } \\
1877\end{array}$ & $\begin{array}{c}\text { Lisboa } \\
1955\end{array}$ \\
\hline $\begin{array}{c}\text { João Andrade } \\
\text { Corvo }\end{array}$ & $\begin{array}{c}\text { Torres Novas } \\
1824\end{array}$ & $\begin{array}{c}\text { Lisboa } \\
1890\end{array}$ \\
\hline $\begin{array}{c}\text { João Augusto } \\
\text { dos Santos }\end{array}$ & Lisboa 1913 & $\begin{array}{c}\text { Lisboa } \\
1987 \\
\end{array}$ \\
\hline $\begin{array}{c}\text { João Cândido } \\
\text { da Silva de } \\
\text { Oliveira }\end{array}$ & Lisboa 1906 & $\begin{array}{l}\text { Lisboa } \\
1991\end{array}$ \\
\hline $\begin{array}{l}\text { João Inácio } \\
\text { Ferreira Lapa }\end{array}$ & $\begin{array}{l}\text { Sátão } \\
1823 \\
\end{array}$ & $\begin{array}{c}\text { Lisboa } \\
1893 \\
\end{array}$ \\
\hline $\begin{array}{l}\text { João Pedro } \\
\text { Miller Pinto de } \\
\text { Lemos Guerra }\end{array}$ & $\begin{array}{c}\text { Vila Flor } \\
1912\end{array}$ & $\begin{array}{l}\text { Lisboa } \\
1993\end{array}$ \\
\hline $\begin{array}{c}\text { João XXI (Pedro } \\
\text { Hispano ou } \\
\text { Pedro Julião) }\end{array}$ & $\begin{array}{l}\text { Lisboa, } \\
1215 ?\end{array}$ & $\begin{array}{l}\text { Viterbo, } \\
\text { Itália } \\
1277\end{array}$ \\
\hline $\begin{array}{c}\text { Joaquim } \\
\text { Barradas da } \\
\text { Silva Fiadeiro }\end{array}$ & $\begin{array}{c}\text { Reguengos } \\
\text { de Monsaraz } \\
1901 \\
\end{array}$ & $\begin{array}{c}\text { Lisboa } \\
1990\end{array}$ \\
\hline $\begin{array}{c}\text { Joaquim } \\
\text { Filipe Nery da } \\
\text { Encarnação } \\
\text { Delgado }\end{array}$ & $\begin{array}{l}\text { Elvas } \\
1835\end{array}$ & $\begin{array}{c}\text { Figueira } \\
\text { da Foz } \\
1908\end{array}$ \\
\hline $\begin{array}{l}\text { Joaquim Vieira } \\
\text { Natividade }\end{array}$ & $\begin{array}{c}\text { Alcobaça } \\
1899 \\
\end{array}$ & $\begin{array}{c}\text { Alcobaça } \\
1968\end{array}$ \\
\hline $\begin{array}{l}\text { Jorge Augusto } \\
\text { da Silva Horta }\end{array}$ & Lisboa 1907 & $\begin{array}{c}\text { Lisboa } \\
1989 \\
\end{array}$ \\
\hline $\begin{array}{l}\text { Jorge Vidal de } \\
\text { Castilho Barreto } \\
\text { e Noronha }\end{array}$ & Lisboa 1880 & $\begin{array}{l}\text { Sidney } \\
1943\end{array}$ \\
\hline $\begin{array}{l}\text { José Alberto de } \\
\text { Faria }\end{array}$ & Lisboa 1888 & $\begin{array}{c}\text { Monte da } \\
\text { Caparica } \\
1958\end{array}$ \\
\hline $\begin{array}{c}\text { José Alberto } \\
\text { de Oliveira } \\
\text { Anchieta }\end{array}$ & Lisboa 1832 & $\begin{array}{c}\text { Caconda, } \\
\text { Angola } \\
1897\end{array}$ \\
\hline $\begin{array}{c}\text { José Anastácio } \\
\text { da Cunha }\end{array}$ & Lisboa 1744 & $\begin{array}{c}\text { Lisboa } \\
1787 \\
\end{array}$ \\
\hline $\begin{array}{c}\text { José António } \\
\text { Marques }\end{array}$ & Lisboa 1822 & $\begin{array}{c}\text { Lisboa } \\
1884\end{array}$ \\
\hline $\begin{array}{c}\text { José António } \\
\text { Serrano }\end{array}$ & $\begin{array}{l}\text { Castelo de } \\
\text { Vide } 1851 \\
\end{array}$ & $\begin{array}{c}\text { Lisboa } \\
1904 \\
\end{array}$ \\
\hline $\begin{array}{c}\text { José Arantes } \\
\text { Pedroso }\end{array}$ & Lisboa 1822 & $\begin{array}{c}\text { Lisboa } \\
1897 \\
\end{array}$ \\
\hline $\begin{array}{c}\text { José de Matos } \\
\text { Sobral Cid }\end{array}$ & $\begin{array}{c}\text { Lamego } \\
1877\end{array}$ & $\begin{array}{c}\text { Lisboa } \\
1941 \\
\end{array}$ \\
\hline $\begin{array}{c}\text { José Luís } \\
\text { Champalimaud }\end{array}$ & $\begin{array}{c}\text { Nova Lisboa } \\
1939 \\
\end{array}$ & $\begin{array}{c}\text { Lisboa } \\
1996 \\
\end{array}$ \\
\hline $\begin{array}{c}\text { José Manuel } \\
\text { Duarte Pinto } \\
\text { Correia }\end{array}$ & $\begin{array}{c}\text { Santarém } \\
1931\end{array}$ & $\begin{array}{c}\text { Lisboa } \\
1988\end{array}$ \\
\hline $\begin{array}{l}\text { José Manuel } \\
\text { Sarmento de } \\
\text { Beires }\end{array}$ & Lisboa 1892 & $\begin{array}{l}\text { Porto } \\
1974\end{array}$ \\
\hline
\end{tabular}

\begin{tabular}{|c|c|c|}
\hline $\begin{array}{c}\text { José Maria } \\
\text { Latino Coelho }\end{array}$ & Lisboa 1825 & $\begin{array}{l}\text { Sintra } \\
1891\end{array}$ \\
\hline $\begin{array}{l}\text { José Pinto } \\
\text { Peixoto }\end{array}$ & $\begin{array}{c}\text { Miuzela } \\
1922\end{array}$ & $\begin{array}{l}\text { Lisboa } \\
1996\end{array}$ \\
\hline $\begin{array}{l}\text { José Sebastião } \\
\text { e Silva }\end{array}$ & $\begin{array}{c}\text { Mértola } \\
1914\end{array}$ & $\begin{array}{c}\text { Lisboa } \\
1972\end{array}$ \\
\hline $\begin{array}{c}\text { José Tiago da } \\
\text { Fonseca de } \\
\text { Oliveira }\end{array}$ & $\begin{array}{c}\text { Lourenço } \\
\text { Marques } \\
1928\end{array}$ & $\begin{array}{l}\text { Lisboa } \\
1992\end{array}$ \\
\hline $\begin{array}{l}\text { José Tomás de } \\
\text { Sousa Martins }\end{array}$ & $\begin{array}{c}\text { Alhandra } \\
1843\end{array}$ & $\begin{array}{c}\text { Alhandra } \\
1897\end{array}$ \\
\hline $\begin{array}{c}\text { José Vicente } \\
\text { Barbosa du } \\
\text { Bocage }\end{array}$ & $\begin{array}{c}\text { Funchal } \\
1823\end{array}$ & $\begin{array}{l}\text { Lisboa } \\
1907\end{array}$ \\
\hline $\begin{array}{c}\text { José Vitorino } \\
\text { Damásio }\end{array}$ & $\begin{array}{c}\text { Vila da Feira } \\
1807 \\
\end{array}$ & $\begin{array}{c}\text { Lisboa } \\
1875 \\
\end{array}$ \\
\hline $\begin{array}{l}\text { Júlio Afrânio } \\
\text { Peixoto }\end{array}$ & $\begin{array}{l}\text { Baía } \\
1876\end{array}$ & $\begin{array}{l}\text { Rio de } \\
\text { Janeiro } \\
1947\end{array}$ \\
\hline $\begin{array}{c}\text { Júlio Ferry do } \\
\text { Espírito Santo } \\
\text { Borges }\end{array}$ & Lisboa 1922 & $\begin{array}{l}\text { Lisboa } \\
1993\end{array}$ \\
\hline Louis Pasteur & $\begin{array}{l}\text { Dôle } \\
1822\end{array}$ & $\begin{array}{c}\text { Villeneuve- } \\
\text { l'Étang } \\
1895 \\
\end{array}$ \\
\hline $\begin{array}{c}\text { Luís Câmara } \\
\text { Pestana }\end{array}$ & $\begin{array}{c}\text { Funchal } \\
1863\end{array}$ & $\begin{array}{c}\text { Lisboa } \\
1899 \\
\end{array}$ \\
\hline $\begin{array}{l}\text { Luís Hernâni } \\
\text { Dias Amado }\end{array}$ & Lisboa 1901 & $\begin{array}{l}\text { Lisboa } \\
1981\end{array}$ \\
\hline $\begin{array}{c}\text { Luís Robertís } \\
\text { Simões Raposo }\end{array}$ & Lisboa 1898 & $\begin{array}{c}\text { Lisboa } \\
1934 \\
\end{array}$ \\
\hline $\begin{array}{c}\text { Manuel } \\
\text { Almeida Amaral }\end{array}$ & Lisboa 1903 & $\begin{array}{c}\text { Lisboa } \\
1960\end{array}$ \\
\hline $\begin{array}{c}\text { Manuel Bento } \\
\text { de Sousa }\end{array}$ & $\begin{array}{l}\text { Porto } \\
1835\end{array}$ & $\begin{array}{c}\text { Lisboa } \\
1899\end{array}$ \\
\hline $\begin{array}{c}\text { Manuel } \\
\text { Bernardo } \\
\text { Barbosa Sueiro }\end{array}$ & $\begin{array}{l}\text { Beja } \\
1894\end{array}$ & $\begin{array}{l}\text { Lisboa } \\
1974\end{array}$ \\
\hline $\begin{array}{l}\text { Manuel Coelho } \\
\text { Mendes Rocha }\end{array}$ & $\begin{array}{l}\text { Figueira da } \\
\text { Foz } \quad 1913\end{array}$ & $\begin{array}{c}\text { Lisboa } \\
1981\end{array}$ \\
\hline $\begin{array}{c}\text { Manuel da } \\
\text { Maia }\end{array}$ & $\begin{array}{l}\text { Lisboa } \\
1677 ?\end{array}$ & $\begin{array}{c}\text { Lisboa } \\
1768 \\
\end{array}$ \\
\hline $\begin{array}{c}\text { Manuel de } \\
\text { Azevedo Fortes }\end{array}$ & Lisboa 1660 & $\begin{array}{c}\text { Lisboa } \\
1749 \\
\end{array}$ \\
\hline $\begin{array}{l}\text { Manuel João } \\
\text { Xavier Morato }\end{array}$ & Lisboa 1906 & $\begin{array}{c}\text { Lisboa } \\
1988 \\
\end{array}$ \\
\hline $\begin{array}{c}\text { Manuel José } \\
\text { Nogueira } \\
\text { Valadares }\end{array}$ & Lisboa 1904 & $\begin{array}{l}\text { Lisboa } \\
1982\end{array}$ \\
\hline $\begin{array}{c}\text { Manuel Nazaré } \\
\text { Cordeiro } \\
\text { Ferreira } \\
\end{array}$ & Lisboa 1895 & $\begin{array}{l}\text { Lisboa } \\
1981\end{array}$ \\
\hline $\begin{array}{l}\text { Marck Anahory } \\
\text { Athias }\end{array}$ & $\begin{array}{c}\text { Funchal } \\
1875\end{array}$ & $\begin{array}{c}\text { Lisboa } \\
1946\end{array}$ \\
\hline $\begin{array}{c}\text { Marie } \\
\text { Sklodowska } \\
\text { Curie }\end{array}$ & $\begin{array}{c}\text { Varsóvia } \\
1867\end{array}$ & $\begin{array}{l}\text { Seaux } \\
1934\end{array}$ \\
\hline Mário Moutinho & $\begin{array}{c}\text { Angra do } \\
\text { Heroísmo } \\
1877\end{array}$ & $\begin{array}{l}\text { Lisboa } \\
1961\end{array}$ \\
\hline $\begin{array}{c}\text { Miguel Ângelo } \\
\text { De Blasco }\end{array}$ & Génova ? & $\begin{array}{c}\text { Lisboa } \\
1791 \\
\end{array}$ \\
\hline $\begin{array}{c}\text { Miguel } \\
\text { Bombarda }\end{array}$ & $\begin{array}{c}\text { Rio de } \\
\text { Janeiro } 1851\end{array}$ & $\begin{array}{c}\text { Lisboa } \\
1910 \\
\end{array}$ \\
\hline $\begin{array}{c}\text { Orlando de } \\
\text { Cunha Ribeiro }\end{array}$ & Lisboa 1911 & $\begin{array}{c}\text { Lisboa } \\
1997 \\
\end{array}$ \\
\hline $\begin{array}{l}\text { Pedro José } \\
\text { Pezerat }\end{array}$ & $\begin{array}{c}\text { Pezérat } \\
\text { (França) } \\
1800\end{array}$ & $\begin{array}{l}\text { Lisboa } \\
1872\end{array}$ \\
\hline $\begin{array}{l}\text { Pedro Manuel } \\
\text { d'Almeida Lima }\end{array}$ & $\begin{array}{l}\text { Lisboa } \\
1903\end{array}$ & $\begin{array}{c}\text { Lisboa } \\
1985\end{array}$ \\
\hline $\begin{array}{c}\text { Pedro } \\
\text { Monjardino }\end{array}$ & Lisboa 1910 & $\begin{array}{c}\text { Lisboa } \\
1969 \\
\end{array}$ \\
\hline Pedro Nunes & $\begin{array}{l}\text { Alcácer do } \\
\text { Sal } 1502 \\
\end{array}$ & $\begin{array}{c}\text { Coimbra } \\
1578 \\
\end{array}$ \\
\hline $\begin{array}{c}\text { Porfírio Pardal } \\
\text { Monteiro }\end{array}$ & $\begin{array}{c}\text { Montelavar } \\
1897\end{array}$ & $\begin{array}{c}\text { Lisboa } \\
1957\end{array}$ \\
\hline
\end{tabular}




\begin{tabular}{|c|c|c|}
\hline $\begin{array}{l}\text { Raul de Mesnier } \\
\text { du Ponsard }\end{array}$ & $\begin{array}{l}\text { Porto } \\
1849\end{array}$ & $\begin{array}{c}\text { Moçam- } \\
\text { bique } \\
1914\end{array}$ \\
\hline $\begin{array}{c}\text { Reinaldo } \\
\text { Manuel dos } \\
\text { Santos }\end{array}$ & Lisboa 1731 & $\begin{array}{l}\text { Lisboa } \\
1791\end{array}$ \\
\hline $\begin{array}{l}\text { Reynaldo dos } \\
\text { Santos }\end{array}$ & $\begin{array}{l}\text { Vila Franca } \\
\text { de Xira } 1880\end{array}$ & $\begin{array}{l}\text { Lisboa } \\
1970\end{array}$ \\
\hline $\begin{array}{c}\text { Ricardo de } \\
\text { Almeida Jorge }\end{array}$ & $\begin{array}{l}\text { Porto } \\
1858\end{array}$ & $\begin{array}{l}\text { Lisboa } \\
1939\end{array}$ \\
\hline $\begin{array}{c}\text { Roberto Duarte } \\
\text { Silva }\end{array}$ & $\begin{array}{c}\text { Santo Antão } \\
\text { Cabo Verde } \\
1837\end{array}$ & $\begin{array}{l}\text { Paris } \\
1889\end{array}$ \\
\hline $\begin{array}{c}\text { Sebastião } \\
\text { Cabral da } \\
\text { Costa Sacadura }\end{array}$ & $\begin{array}{c}\text { Abrunhosa- } \\
\text {-a-Velha } \\
\text { (Mangualde) } \\
1872\end{array}$ & $\begin{array}{l}\text { Lisboa } \\
1966\end{array}$ \\
\hline $\begin{array}{c}\text { Thomas Alva } \\
\text { Edison }\end{array}$ & $\begin{array}{l}\text { Milan } \\
1847\end{array}$ & $\begin{array}{c}\text { West } \\
\text { Orange } \\
1931\end{array}$ \\
\hline $\begin{array}{c}\text { Tomás António } \\
\text { da Guarda } \\
\text { Cabreira }\end{array}$ & $\begin{array}{l}\text { Tavira } \\
1865\end{array}$ & $\begin{array}{c}\text { Portimão } \\
1918\end{array}$ \\
\hline $\begin{array}{c}\text { Thomaz de } \\
\text { Melo Breyner } \\
\text { (4 Conde de } \\
\text { Mafra) }\end{array}$ & Lisboa 1866 & $\begin{array}{l}\text { Lisboa } \\
1933\end{array}$ \\
\hline $\begin{array}{l}\text { Victor Hugo } \\
\text { Moreira Fontes }\end{array}$ & Lisboa 1893 & $\begin{array}{l}\text { Lisboa } \\
1979\end{array}$ \\
\hline $\begin{array}{c}\text { Virgílio César } \\
\text { da Silveira } \\
\text { Machado }\end{array}$ & $\begin{array}{l}\text { Queluz } \\
1859\end{array}$ & $\begin{array}{l}\text { Lisboa } \\
1927\end{array}$ \\
\hline $\begin{array}{l}\text { Wilhelm } \\
\text { Conrad Von } \\
\text { Röntgen }\end{array}$ & $\begin{array}{l}\text { Lennep } \\
1845\end{array}$ & $\begin{array}{c}\text { Munique } \\
1923\end{array}$ \\
\hline
\end{tabular}

O número de cientistas homenageados obtido neste estudo não coincide com o de arruamentos. Esta diferença explica-se pelo facto de existirem dois arruamentos que fazem homenagem a Egas Moniz (Avenida Professor Egas Moniz - Campo Grande e Rua Egas Moniz - Alto do Pina) e dois que fazem homenagem a Dom João de Castro (Rua Dom João de Castro - Ajuda e Alcântara e Travessa Dom João de Castro - Ajuda).

Em resumo, podem então citar-se os seguintes valores:

- Número Total de Arruamentos com Topónimos Oficiais - 4038.

- Número Total de Arruamentos com Antropónimos - 1535.

- Número Total de Arruamentos com Antropónimos de Cientistas - 146.

- Número de Cientistas Homenageados - 144 (143 homens e 1 mulher).

\section{Caracterização dos Arruamentos}

Será curioso verificar como e por onde se distribuem as vias com topónimos de cientistas, bem como alguns dados sobre os cientistas homenageados. O principal tipo de via escolhido para homenagear os cientistas são as ruas $(80,6 \%)$ seguindo-se as avenidas (11,6\%) e distribuindo-se os restantes $7,6 \%$ por outros tipos de vias: praça, largo, alameda, escadaria e travessa (Figura 1). Os arruamentos que homenageiam

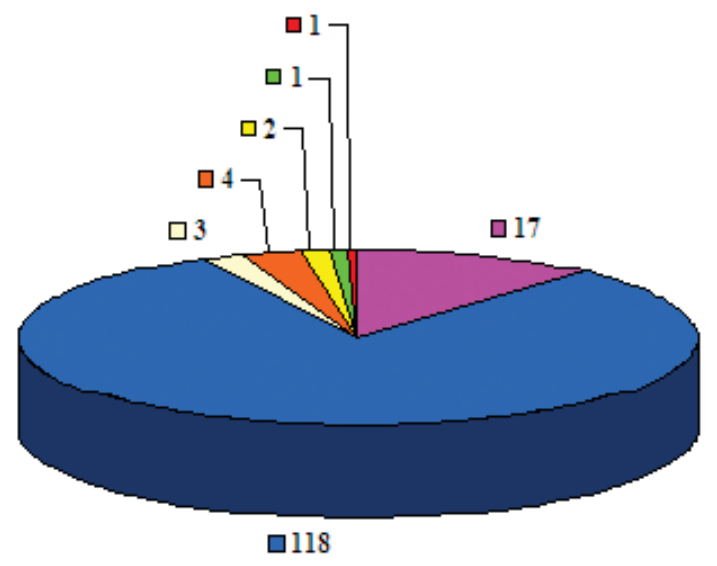

\begin{tabular}{|l|}
\hline Avenida \\
$\square$ Rua \\
$\square$ Praça \\
$\square$ Largo \\
$\square$ Alameda \\
$\square$ Escadaria \\
$\square$ Travessa \\
\hline
\end{tabular}

Figura 1 Tipo de via com topónimos de cientistas

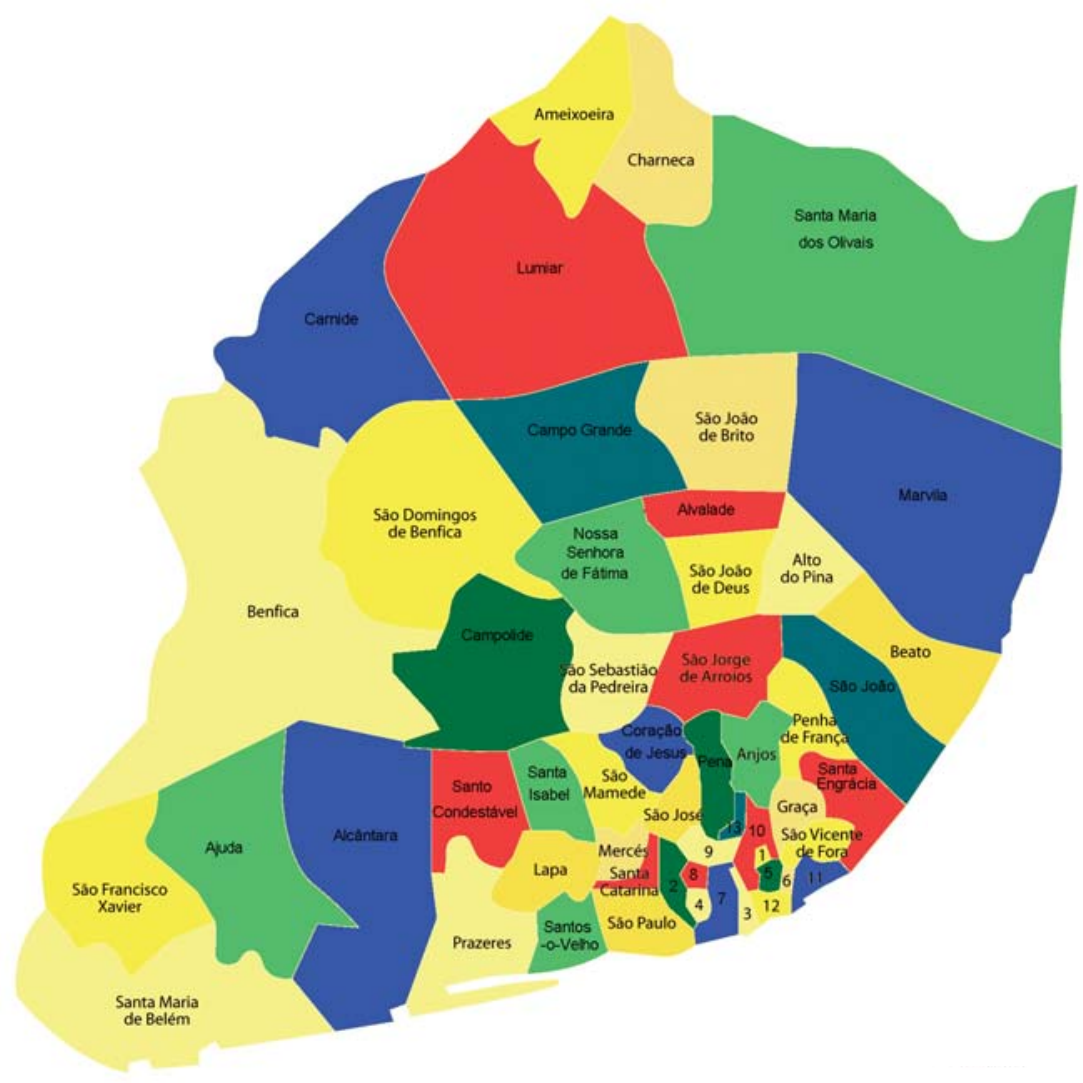

Legenda:

(3)

Freguesia sem topónimos de cientistas

1 - Castelo

4 - Mártires

7 - São Nicolau

10 - Santiago

13 - Socorro os cientistas estão globalmente distribuídos por todo o Concelho de Lisboa. Com excepção de 17 freguesias que não o fazem na sua toponímia, as restantes têm pelo menos um arruamento em que o fazem (Figura 2 e Tabela 2). 
Tabela 2 Número de arruamentos por freguesia com topónimos que homenageiam cientistas

\begin{tabular}{|c|c|c|}
\hline Freguesia & $\begin{array}{l}\text { № Total de } \\
\text { Arruamentos }\end{array}$ & № de Arruamentos que pertencem a mais de uma Freguesia \\
\hline Ajuda & 9 & 1 (Alcântara) \\
\hline Alcântara & 3 & 1 (Ajuda) \\
\hline Alto do Pina & 8 & 1 (S. Jorge Arroios); 1 (Alvalade, S. João de Brito e S. João de Deus) \\
\hline Alvalade & 1 & 1 (Alto do Pina, S. João de Brito e S. João de Deus) \\
\hline Ameixoeira & 1 & \\
\hline Anjos & 1 & \\
\hline Beato & 3 & \\
\hline Benfica & 7 & \\
\hline Campo Grande & 4 & \\
\hline Campolide & 6 & \\
\hline Carnide & 8 & 1 (Lumiar) \\
\hline Coração de Jesus & 2 & 1 (São Jorge de Arroios); 1 (Pena) \\
\hline Lumiar & 25 & 1 (Carnide) \\
\hline Madalena & 1 & \\
\hline Mártires & 1 & \\
\hline Marvila & 4 & \\
\hline N. Sra. de Fátima & 8 & 1 (São Sebastião da Pedreira) \\
\hline Pena & 5 & 1 (Coração de Jesus); 1 (Santa Justa) \\
\hline Penha de França & 3 & \\
\hline Prazeres & 2 & \\
\hline Santa Engrácia & 1 & \\
\hline Santa Isabel & 1 & \\
\hline Santa Justa & 1 & 1 (Pena) \\
\hline Santa Maria de Belém & 1 & \\
\hline Santa Maria dos Olivais & 6 & \\
\hline Santiago & 1 & \\
\hline Santo Condestável & 1 & \\
\hline Santos-O-Velho & 2 & \\
\hline São Domingos de Benfica & 11 & \\
\hline São Francisco Xavier & 1 & \\
\hline São João & 1 & \\
\hline São João de Brito & 5 & 1 (Alto do Pina; Alvalade, S. João de Deus) \\
\hline São João de Deus & 9 & 1 (Alto do Pina; Alvalade, S. João de Brito); 1 (S. Jorge de Arroios) \\
\hline São Jorge de Arroios & 7 & 1 (Alto do Pina); 1 (Coração de Jesus); 1 (S. João de Deus); 1 (São Sebastião da Pedreira) \\
\hline São Sebastião da Pedreira & 7 & 1 (Nossa Senhora de Fátima); 1 (São Jorge de Arroios) \\
\hline \multirow[t]{2}{*}{ São Vicente de Fora } & 1 & \\
\hline & Total-158 & \\
\hline
\end{tabular}

A Tabela 2 mostra a distribuição dos 146 arruamentos pelas 36 freguesias. É de referir que alguns arruamentos pertencem a mais de uma freguesia, pelo que o número total de arruamentos que se utiliza na comparação entre freguesias não é 146, mas sim 158. De entre as várias freguesias destaca-se a do Lumiar com 25 cientistas homenageados. As freguesias que não homenageiam cientistas na sua toponímia são, nomeadamente, a do Castelo, Charneca, Encarnação, Graça, Lapa, Mercês, Sacramento, Santa Catarina, Santo Estêvão, São Crisóstomo e São Lourenço, São José, São Mamede, São Miguel, São Nicolau, São Paulo, Sé e Socorro. Localizam-se todas na zona antiga da cidade de Lisboa, à excepção da freguesia da
Charneca, a norte da Cidade. Tal não é surpresa pois, como já se referiu anteriormente, a toponímia antiga não contempla muitos antropónimos.

Dos números acima citados pode verificar-se que dos arruamentos com topónimos oficiais só $4 \%$ fazem homenagem a cientistas. Se compararmos o número de cientistas identificados 
neste trabalho (144) e o número total de antropónimos na toponímia de Lisboa (1535), verifica-se que só $9 \%$ dos arruamentos com antropónimos se referem a cientistas. Apenas por curiosidade, uma análise às bases de dados Corvusbase-GEO e CMT-CML mostra que as actividades mais exercidas pelos homenageados na toponímia de Lisboa são escritor, jornalista, militar, médico, político e professor universitário. A carência de cientistas pode, em parte, ficar a dever-se ao facto de que muitos dos cientistas seleccionados neste estudo não foram escolhidos para dar nome às ruas de Lisboa por exercerem a actividade científica, mas por outra(s) actividade(s) mais popular(es) ou mais reconhecidas socialmente, como por exemplo: a medicina, a política e o ensino.

A maioria dos cientistas homenageados nasceram em Portugal - 114. Vinte e cinco nasceram no estrangeiro e 5 não se sabe o seu local de nascimento.

Na Figura 3 apresenta-se a distribuição do número de homenageados pelos países onde nasceram. Salienta-se que muitos dos que não nasceram em Portugal estudaram e/ou desenvolveram a sua actividade profissional ou parte dela em Portugal, não sendo por isso considerados cientistas estrangeiros [17].

Consideraram-se como cientistas estrangeiros 11 dos 25 nascidos fora de Portugal, a saber, Alberto Santos Dumont (1873-1932), Alexandre Fleming (1881-1955), Benjamin Franklin (1706-1790), Gugliemo Marconi (1874-1937), Gustave Eiffel (1832-1923), Isaac Newton (1642-1727), Júlio Afrânio Peixoto (1876-1947), Louis Pasteur (1822-1895), Marie Curie (1867-1934), Thomas Edison (1847-1931) e Wilhelm Roentgen (1845-1923).

Para os nascidos em Portugal apresenta-se na Figura 4 a distribuição do seu local de nascimento por Distrito. Os cientistas homenageados na toponímia de Lisboa que nasceram em Portugal, são oriundos, praticamente, de todos os distritos do país, à excepção de Vila Real. Como seria expectável, Lisboa é o distrito onde nasceu o maior número dos homenageados, cerca de $42 \%$.

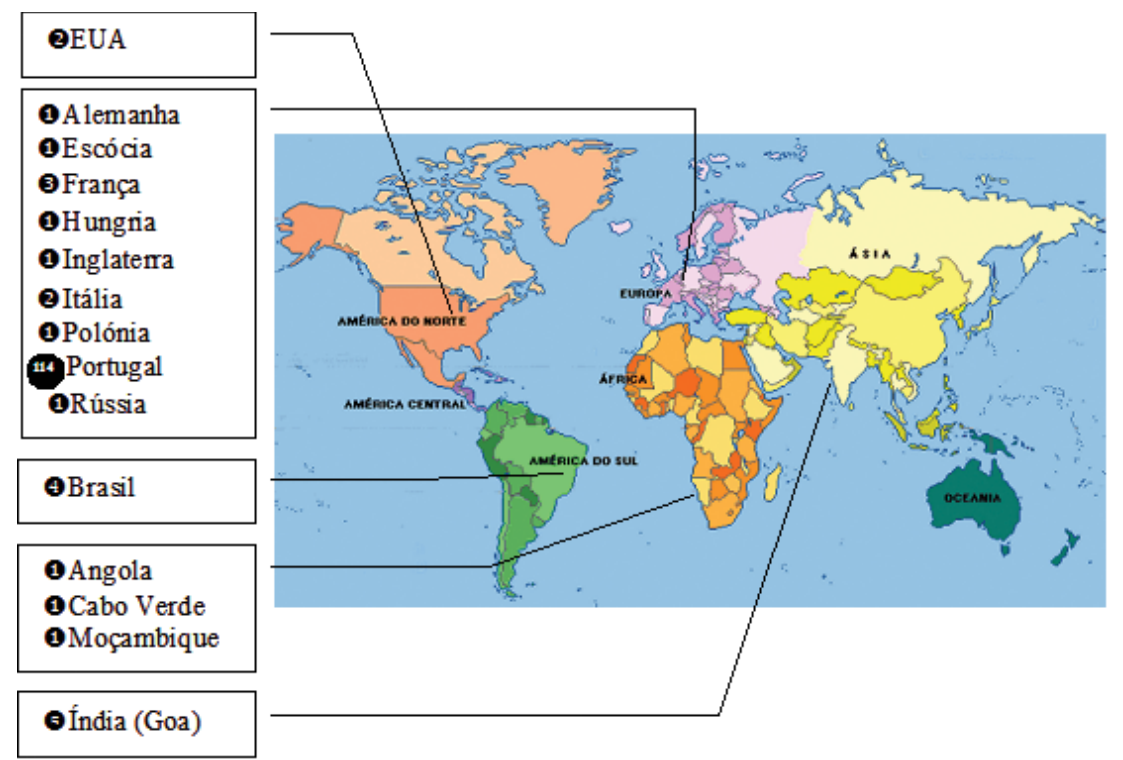

Figura 3 Local onde nasceram os cientistas homenageados na Toponímia de Lisboa

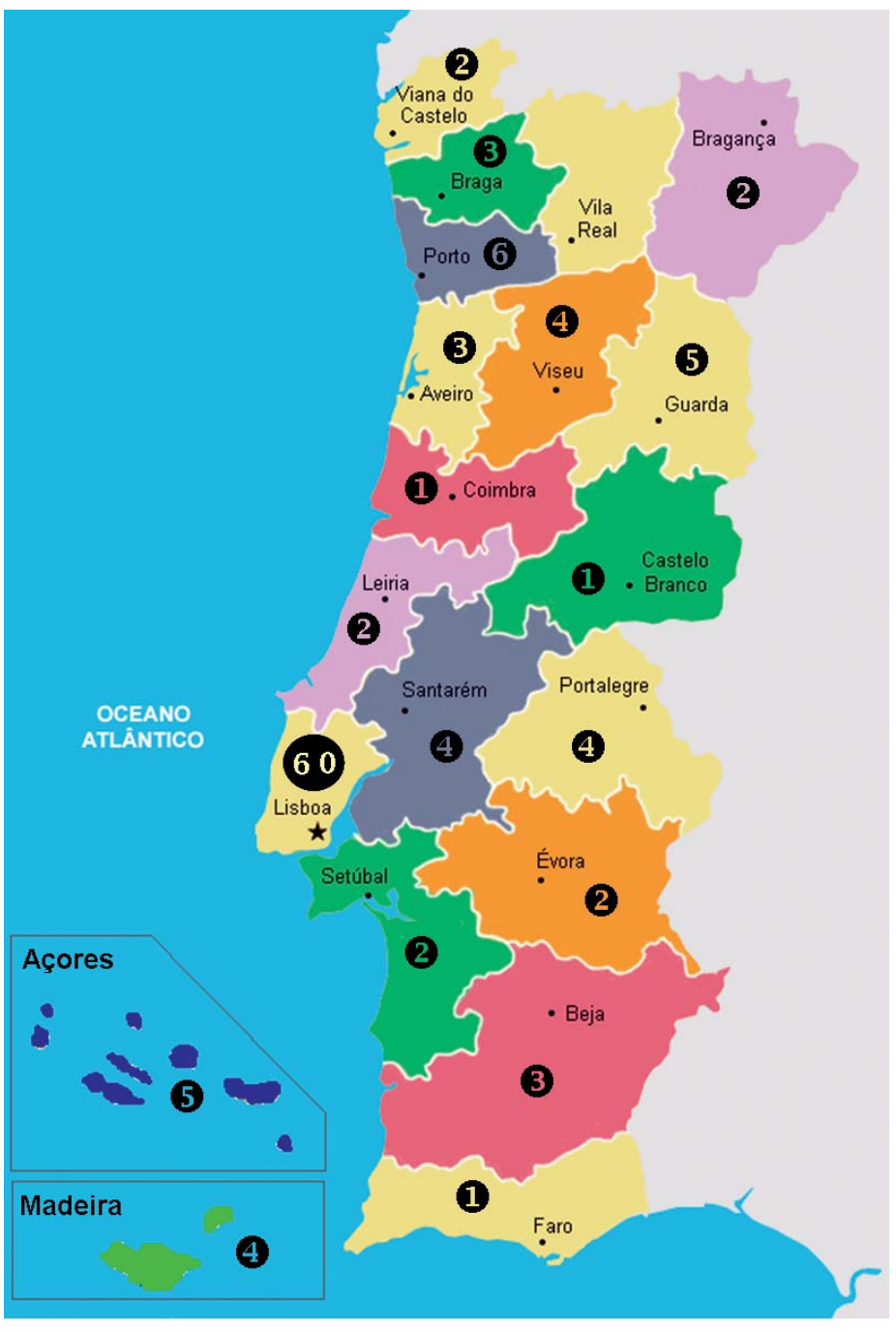

Local desconhecido 5

Figura 4 Local de nascimento dos cientistas nascidos em território nacional 
A maioria dos cientistas homenageados $(85 \%)$ nasceu no século XIX e na primeira metade do século XX (Figura 5) e na generalidade foram homenageados após a sua morte $(96,6 \%)$. As excepções são Alberto Santos Dumont (1873-1932), Egas Moniz (1874-1955), Luís Hernâni Dias Amado (1901-1991), Marie Curie (1867-1934) e Virgílio Machado (1859-1927), que foram homenageados em vida, sendo as datas dos editais toponímicos de 1923, 1926, 1981, 1932 e 1903, respectivamente.

\section{ConCLUSÃo}

Seria interessante que o presente estudo pudesse ser alargado a outras cidades do país. No entanto, se para Lisboa as bases de dados não estão actualizadas e as dificuldades de obter dados fiáveis são grandes, para o restante país são ainda maiores. Apenas para se ter uma ideia, é muito fácil encontrar "falsos cientistas", isto é, encontrar ruas com o nome de cientistas, mas em que se homenageiam outras personagens homónimas [18].

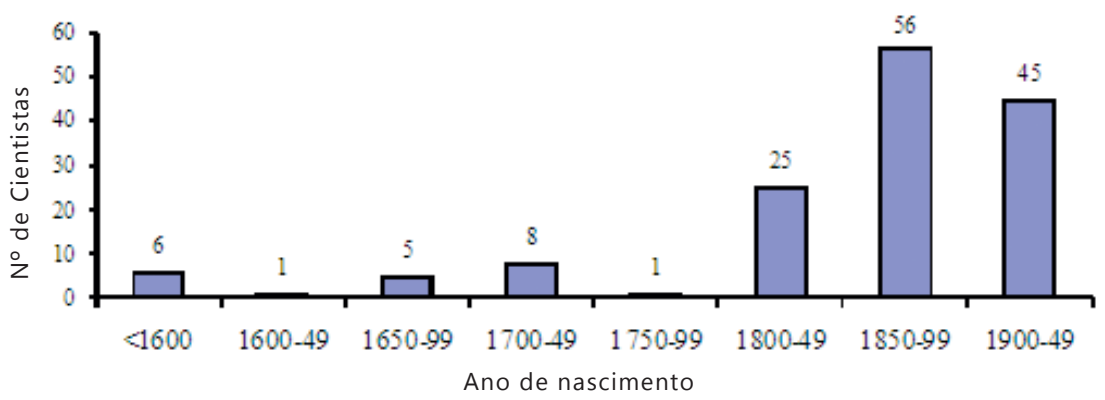

Figura 5 Número de cientistas homenageados em função do respectivo ano de nascimento

Também o número de cientistas reconhecidos ao longo do tempo foi variando. Verifica-se que os primeiros editais de topónimos de cientistas ocorreram no final do século XIX e que o número de topónimos foi oscilando entre os 11 e os 7 por década até ao início dos anos setenta, do século XX (Figura 6). Houve um crescimento nas últimas décadas do século passado, atingindo o máximo de arruamentos com topónimos de cientistas na década de 90 .
Tal distinção só pode fazer-se recorrendo aos editais camarários ou a bases de dados completas e actualizadas, o que a maioria das vezes não é possível.

\section{Referências e Notas}

[1] Dicionário da Língua Portuguesa Contemporânea, Academia das Ciências, Lisboa, 2001.

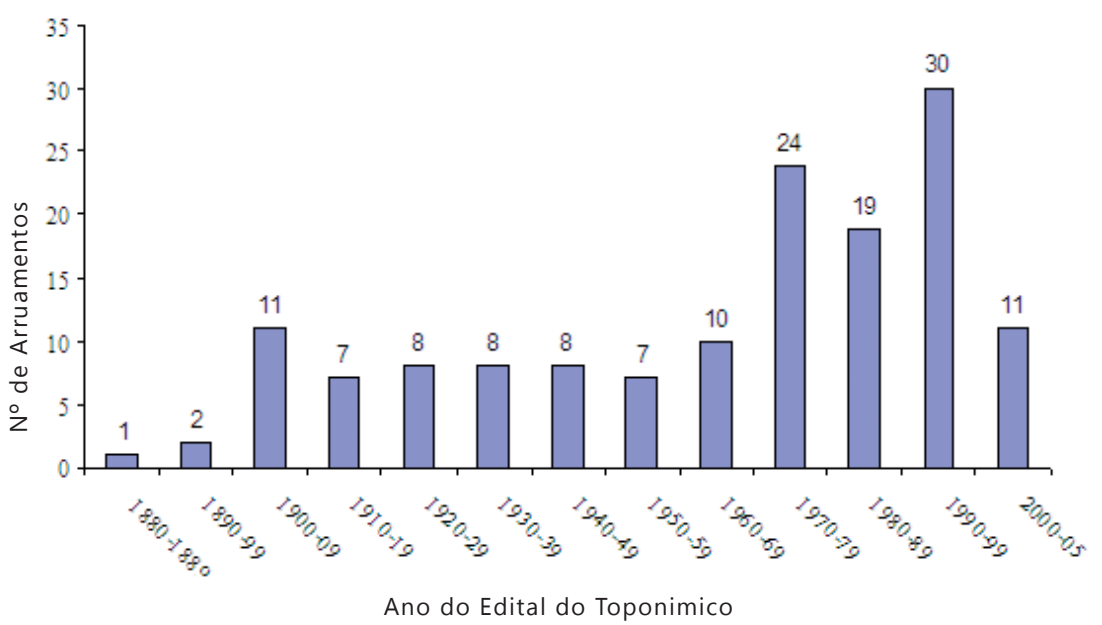

Figura 6 Número de arruamentos que homenageiam cientistas em função da data do edital toponímico

[2] O. Pombo, Apontamentos sobre o conceito de epistemologia e o enquadramento categorial de diversidade de concepções de ciência, http://www. educ.fc.ul.pt/docentes/opombo/investigacao/cat_epist.htm, acedido em 5 de Janeiro de 2007.

[3] M. J. M. Fonseca, "Em torno do Conceito de Ciência", Millenium on-line, Revista do Instituto Politécnico de Viseu, n $1,2^{a}$ ed., 39-51, http://www.ipv.pt/millenium/Fonseca_ect1, acedido em 3 de Março de 2007.

[4] K. C. Jones, A. J. Gaudin, Introdução À Biologia, $3^{\mathrm{a}}$ ed., Fundação Calouste Gulbenkian, Lisboa, 2000.

[5] Gilberto Câmara (2004) - entrevista publicada por A. Kassab (2004). "Dos paradigmas da ciência ao conhecimento em construção", Jornal da Unicamp. Universidade Estatual de Campinas (9 a 15 de Agosto), p 5-7, http://www.inpe.br/institucional/pdf/ unicamp_9agosto2004.pdf, acedido em 5 de Janeiro de 2007.

[6] R. Gonçalves-Maia, O Legado de Prometeu-Uma Viagem na História das Ciências, Escolar Editora, Lisboa, 2006, p.21

[7] "Ciência para o século XXI - Um novo Compromisso", Conferência realizada em Budapeste sob a égide da Organização das Nações Unidas para a Educação, Ciência e Cultura (UNESCO) e do Conselho Internacional da Ciência (ICSU), ed. UNESCO, Paris, 1999.

[8] J. Gribbin, História da Ciência de 1543 ao Presente, Publicações Europa-América, Lisboa, 2005.

[9] S. Salvado, C. Batalha, "Toponímia: Notas sobre o Estudo do seu Suporte Legal", em II Jornadas sobre Toponímia de Lisboa, Coord. A. Trindade e T. Pereira, Câmara Municipal de Lisboa: DMAGGRH/DA, Lisboa, 1997.

[10] I. Moita, "A Influência da Política na Toponímia de Lisboa”, em II Jornadas sobre Toponímia de Lisboa, Coord. A. Trindade e T. Pereira, Câmara Municipal de Lisboa: DMAGGRH, Lisboa, 1997.

[11] Paula Machado, "Os estrangeiros vistos nas Ruas de Lisboa", em III Jornadas sobre Toponímia de Lisboa -1998, Coord. Edição A. Trindade, P. Machado e T. Pereira, Câmara Municipal de Lisboa: Departamento de Administração Geral, Lisboa, 2000.

[12] Referência 10, p.151.

[13] Com o topónimo Santo António existem em Lisboa 23 vias (Alameda da 
Quinta de Santo António, Alameda de Santo António dos Capuchos, Beco de Santo António, Calçada de Santo António, Largo de Santo António à Sé, Rua de Santo António a Belém, Rua de Santo António à Estrela, Rua de Santo António da Glória, Rua de Santo António da Sé, Rua de Santo António dos Capuchos, Rua do Milagre de Santo António, Rua do Vale de Santo António, Travessa de Santo António, Travessa de Santo António a Belém, Travessa de Santo António à Graça, Travessa de Santo António à Junqueira, Travessa de Santo António a Santos, Travessa de Santo António da Sé).

[14] Comunicação pessol da investigadora do GEO, Dr. ${ }^{a}$ Ana Homem de Melo (1 de Junho de 2006).

[15] Valor fornecido pela Dr. ${ }^{a}$ Teresa Pereira da CMT-CML (comunicação pessoal, 17 de Janeiro de 2007).

[16] Valor obtido com a colaboração da Dr. ${ }^{a}$ Ana Homem de Melo, a partir dos dados da Corvusbase - Base de Dados de Toponímia. O critério de contagem "exclui pátios, vilas, quintas, bairros, casas, denominações não oficiais, e topónimos duplicados (p.ex ${ }^{\circ}$ Dona Estefânia só entra uma vez na contagem, apesar de ter Largo, Rua e Travessa).
Quanto aos jardins apenas foram considerados os que têm nome por decisão da Comissão de Toponímia, pois todos os outros foram denominados pela antiga Repartição de Jardins, resultando na prática que ninguém os conheça (p. ex ${ }^{\circ}$ o Jardim da Estrela é o Jardim Guerra Junqueiro) e não são utilizados nem oficialmente, pois não existe edital toponímico que os denomine." (1 de Junho de 2007).

[17] Estão nestas condições os seguintes: Abade de Faria (1746-1819), Agostinho Lourenço (1822-1893), Aires de Sousa (1905-1980), Bartolomeu de Gusmão (1685-1724), Gama Pinto (1853-1945), Carlos Mardel (1695-1763), Francisco Silva Teles (1860-1930), Georges Zbyszeweski (1909-1999), José Luís Champalimaud (1939-1996), Tiago Oliveira (1928-1992), Miguel Ângelo de Blasco (?-1791), Miguel Bombarda (1851-1910), Pedro José Pezerat (1800-1872) e Roberto Duarte Silva (1837-1889).

[18] Por exemplo: Álvaro Rodrigues Machado (1879-1946) Professor de Física e responsável do Observatório Meteorológico da Faculdade de Ciências da Universidade do Porto, confusão com Álvaro Augusto Machado (1874-1944)
Arquitecto, Professor no Instituto Superior Técnico, homenageado na toponímia da freguesia de Marvila, Lisboa; Bernardino Camilo Cincinato da Costa (1866-1930) Engenheiro Agrónomo e Médico Veterinário, Professor Catedrático no Instituto de Agronomia e Veterinária, confusão com Bernardino António da Costa (1836-1908) Bombeiro Municipal, homenageado na toponímia da freguesia de S. Paulo, Lisboa; José Júlio Bettencourt Rodrigues (18451893) Químico, Mineralogista, Investigador e Professor na Escola Politécnica, confusão com José Rodrigues de Carvalho (1828-1887) Pintor, homenageado na toponímia da freguesia de Marvila; Luís António Rebelo da Silva (1783-1847) Agrónomo, confusão com o seu filho Luís Augusto Rebelo da Silva (1822-1871), Historiador, Político e Jornalista, homenageado na toponímia da freguesia da São Jorge de Arroios, Lisboa; Luís da Silva Mouzinho de Albuquerque (1792-1846) Militar da arma de engenharia, Poeta, Cientista e Político português, confusão com Joaquim Augusto Mouzinho de Albuquerque (1855-1902) Militar e Governador Ultramarino, homenageado na toponímia de Lisboa.

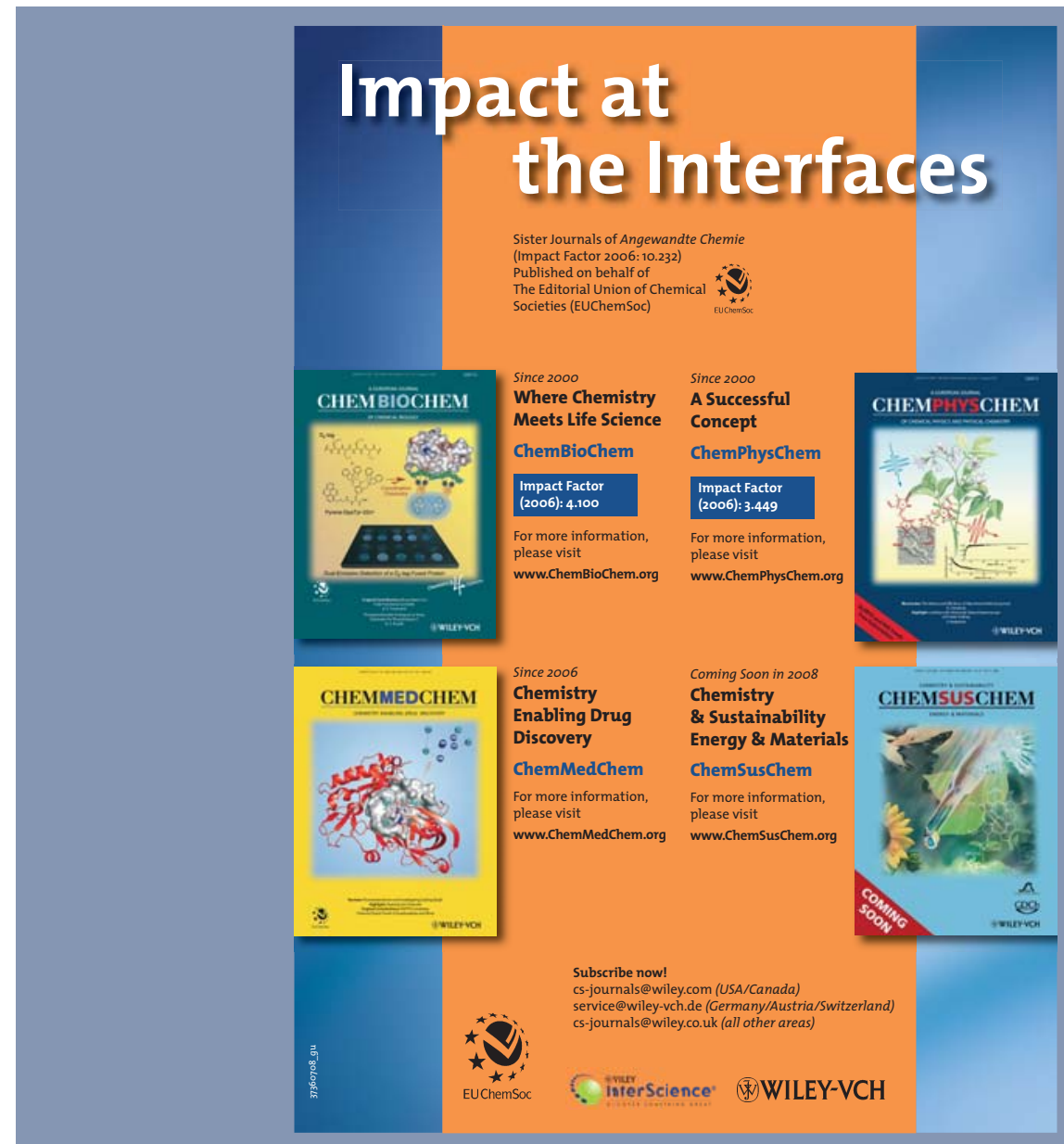




\section{Actualidade Científica}

\section{Proteína Fluorescente Verde (GFP)}

O Prémio Nobel da Química 2008 foi atribuído a Osamu Shimomura do Japão e aos cientistas americanos Martin Chalfie e Roger Tsien pelos seus contributos para a descoberta e desenvolvimento da proteína fluorescente verde (GFP) e dos seus derivados como uma ferramenta actualmente indispensável em medicina e biologia. Enquanto que as moléculas fluorescentes pequenas (como o isocianato de fluoresceína) são fortemente fototóxicas quando usadas em células vivas, as proteínas fluorescentes, como a proteína fluorescente verde, são menos nocivas quando iluminadas em células vivas.

Este facto despoletou o desenvolvimento de sistemas de microscópios fluorescentes altamente automatizados para observação de células vivas ao longo do tempo durante a expressão de uma ou mais proteínas marcadas com proteínas fluorescentes. A análise destes filmes permitiu redefinir a compreensão de muitos processos biológicos, tais como o transporte e o enrolamento de proteínas (protein folding) e a dinâmica do ARN, cuja análise no passado foi efectuada em material fixo, i.e. material morto. Uma outra poderosa aplicação da GFP é a expressão desta proteína em pequenos conjuntos de células específicas. Isto permite aos investigadores a detecção óptica de tipos específicos de células in vitro ou mesmo in vivo.

A proteína fluorescente verde é constituída por 238 aminoácidos e exibe uma fluorescência verde quando exposta a uma luz azul. Foi isolada pela primeira vez por Osamu Shimomura em 1962 a partir da alforreca Aequorea Victoria. Shimomura descobriu que, para ser bioluminescente, a alforreca Aequorea liberta iões cálcio. Estes ligam-se a uma proteína, que ele designou por aequorin, que liberta luz azul quando ocorre essa ligação. A luz azul é então absorvida pela proteína fluorescente verde, que, em consequência, liberta luz de cor verde.

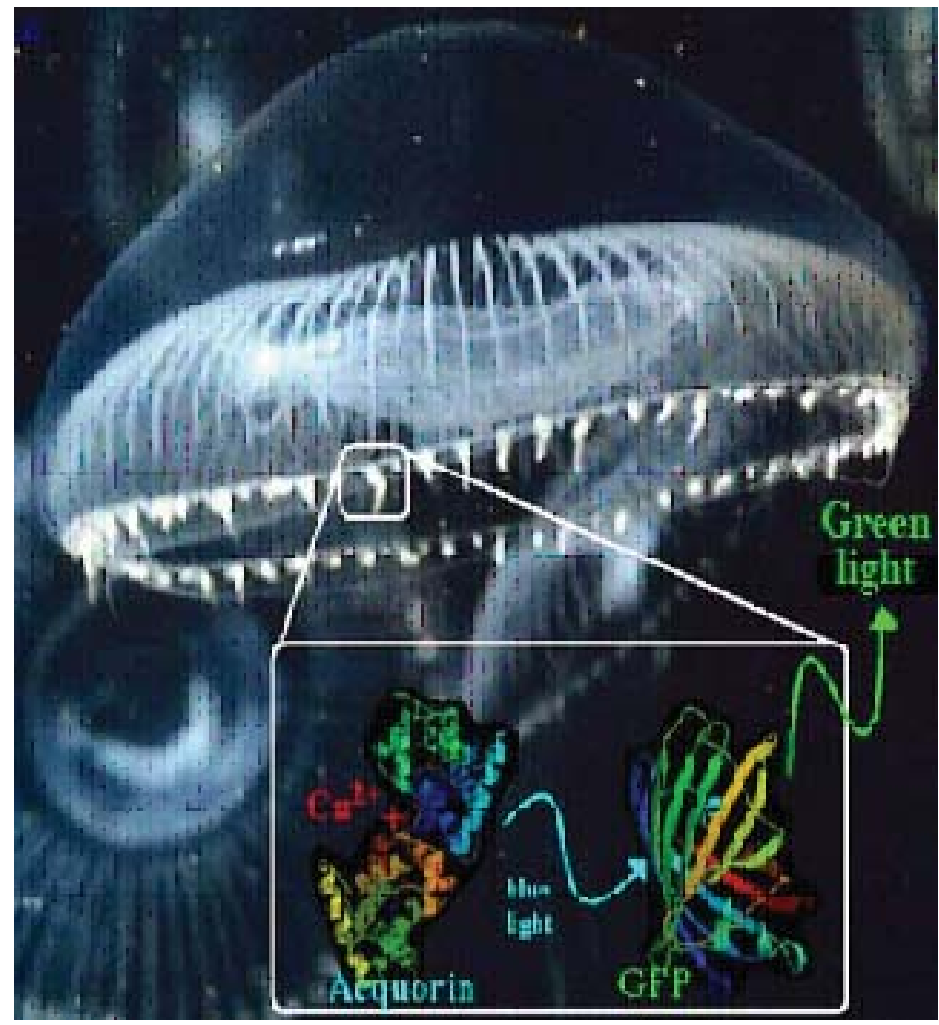

Figura 1 Foto-receptores da Aequorea victoria bioluminescente (Foto: cortesia de Osamu Shimomura)

A GFP tem uma estrutura em barril $\beta$ ( $\beta$-barrel) típica, consistindo numa camada $\beta$ ( $\beta$-sheet) com uma hélice $\alpha$ ( $\alpha$-helix) contendo o fluoróforo percorrendo o centro. Enquanto que a maioria de outras proteínas cromofóricas devem a sua cor à presença de ligandos ou metais externos, o cromóforo da GFP é apenas formado pela sequência dos seus aminoácidos, especificamente formada pela ciclização de três aminoácidos (Ser65-Tyr66-Gly67) seguida de um passo final de oxidação. Contudo, o cromóforo apenas exibe cor quando colocado na estrutura barril $\beta$, que protege o fluoróforo da extinção pelo microambiente circundante, e quando o cromóforo se encontra ligado de forma não covalente a outros aminoácidos espacialmente colocados na vizinhança próxima.

Douglas Prasher foi o primeiro a visionar a utilização da GFP da alforreca para assinalar quando é que uma proteína estaria a ser produzida numa célula. O fundamento desta ideia residia na possibilidade de que se fosse possível ligar a GFP a uma proteína sem cor, esta proteína específica poderia ser seguida, seguindo a fluorescência verde da GFP, tornando assim possível a monitorização de processos que até então eram invisíveis.

Em 1988, Martin Chalfie soube pela primeira vez da GFP e pretendeu então usá-la como marcador que poderia ser ligado a um promotor (promoter). O promotor é uma região do ADN localizada em frente de um gene, que controla a intensidade da expressão de uma proteína. Ligando a GFP a um promotor, Chalfie esperava que a GFP fosse produzida sempre que o promotor a que ela se encontrava ligada fosse activado. Deste modo, a fluorescência da GFP poderia ser usada para indicar a activação do promotor "etiquetado" com a GFP. Após a publicação da sequência da GFP por Douglas Prasher na revista Gene, Prasher enviou um clone da GFP a Chalfie. Este passou-o à estudante de graduação Ghia Euskirchen, que estava a realizar um estágio no seu laboratório, que conseguiu incorporar o gene da GFP na $E$. coli de modo que estas bactérias exibiam uma fluorescência verde quando irradiadas com 
luz azul. Chalfie e colaboradores publicaram os seus resultados na revista Science de 14 de Feveiro de 1994.

No entanto, muitos investigadores duvidavam que o gene da GFP fosse capaz, por si só, de produzir esta proteína. Contudo, a publicação do artigo de Chalfie em 1994 tornou este gene popular como marcador genético. Cientistas descobriram que poderiam ligar o gene da GFP a outros genes e que, em vez de usarem testes complicados para verificarem se tinham conseguido inserir um determinado gene num organismo, poderiam simplesmente iluminar com luz azul e procurar a emissão verde. É conhecido que muitos genes produzem proteínas que necessitam de interagir com outras proteínas, produzidas por outros genes, para funcionarem. Surpreendentemente, a GFP não necessita de quaisquer genes adicionais ou ligandos externos porque toda a informação necessária para produzir o seu cromóforo está codificada na sua sequência primária. É esta particularidade que torna a GFP única.

Enquanto que Shimomura, Prasher e Chalfie desenvolveram uma componente mais instrumental ao obterem a GFP das alforrecas e ao mostrarem que pode ser usada como traçador molecular, Roger Tsien foi responsável por desvendar o modo de funcionamento da GFP e por desenvolver novas técnicas e mutantes da GFP. O primeiro grande desenvolvimento foi uma mutação pontual (single point mutation) (S65T) relatada em 1995 na revista Nature por Roger Tsien. Esta mutação melhorou extraordinariamente as características espectrais da GFP, resultando num aumento de fluorescência, fotoestabilidade e um desvio do principal pico de excitação para 488nm mantendo o pico de emissão a $509 \mathrm{~nm}$. Adicionalmente, a mutação pontual F64L resultou na obtenção de uma GFP que possui um coeficiente de extinção $(\varepsilon)$ de 55000 $\mathrm{M}^{-1} \mathrm{~cm}^{-1}$ e um rendimento quântico de fluorescência muito elevado $\left(\varnothing_{\mathrm{F}}=\right.$ $=0,60)$. Esta forma foi designada por enhanced GFP (EGFP). Têm sido preparados muitos mutantes da GFP para responder ao seu elevado potencial para um uso mais extensivo e às necessidades dos investigadores.

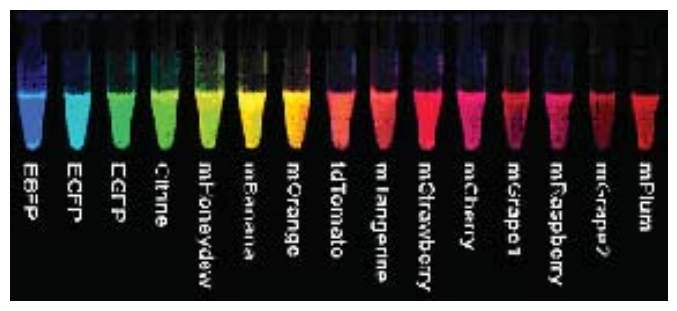

Figura 2 Derivados da GFP com diferentes cores e fluorescência aumentada que cobrem o espectro visível foram desenvolvidos no laboratório de Roger Tsien. " $E$ " indica as versões com fluorescência aumentada, " $m$ " são proteínas monomericas e " $t d$ " é um dímero cabeça-cauda)

Foram preparadas proteínas com fluorescência azul (EBFP, EBFP2, Azurite, mKalama1), proteínas com fluorescência ciano (ECFP, Cerulean, CyPet) e proteínas com fluorescência amarela (YFP, Citrine, Venus, YPet). Os derivados BFP (excepto $m$ Kalama1) possuem a substituição $\mathrm{Y} 66 \mathrm{H}$. A mutação crítica nos derivados ciano é a substituição Y66W, que provoca que o cromóforo se forme com uma componente indole em vez de fenol. São necessárias várias mutacões adicionais compensadoras no barril circundante para recuperar o brilho deste cromóforo modificado devido ao maior volume do grupo indole. $\mathrm{O}$ desvio para o vermelho dos derivados YFP resulta da mutação T203Y e deve-se a interacções de empilhamento dos electrões $\pi$ entre os resíduos de tirosina substituída e o cromóforo.

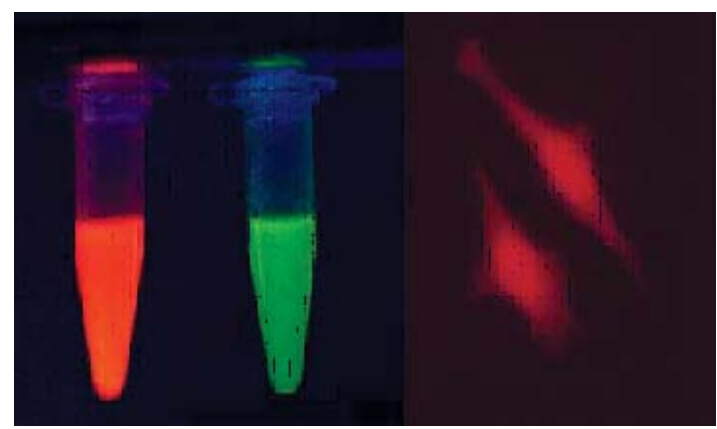

Figura 3 DsRed e GFP (cortesia da Clontech); Dsred é normalmente tetramérica, mas estão actualmente disponíveis formas monoméricas (a figura da direita apresenta DsRed monomérica, cortesia da Clontech)

Estas variantes espectrais são muitas vezes usadas em experiências de transferência de energia de resonância (fluorescence resonance energy transfer, FRET). A utilização de indicadores FRET geneticamente codificados sensíveis a moléculas sinalizadoras de células tem permitido seguir opticamente a actividade celular em tempo real.

Há também mutantes da GFP sensíveis ao $\mathrm{pH}$, conhecidos como pHluorins. Explorando a alteração brusca de $\mathrm{pH}$ que ocorre quando se dá a fusão de vesículos sinápticos, têm sido usados pHluorins ligados a synaptobrevina para visualizar a actividade sináptica de neurónios.

Finalmente, um grande desenvolvimento nas aplicações da GFP ocorreu quando Sergey Lukyanov descobriu algumas proteínas do tipo da GFP em corais não fluorescentes. Lukyanov descobriu uma nova proteína fluorescente vermelha, designada por DsRed. Foram também descobertas novas proteínas do tipo da GFP em organismos marinhos que não são bioluminescentes e muitas vezes nem sequer fluorescentes. Em Agosto de 2007 Lukyanov relatou a existência de uma proteína fluorescente de elevado brilho que emite no infra-vermelho próximo. A forma monomérica desta proteína foi designada por $m$ Kate.

\section{REFERÊNCIAS}

- http://www.conncoll.edu/ccacad/ zimmer/GFP-ww/shimomura.html

- http://en.wikipedia.org/wiki/Green_ Fluorescent_Protein

\section{Melinda C. Noronha} CQE-IST 


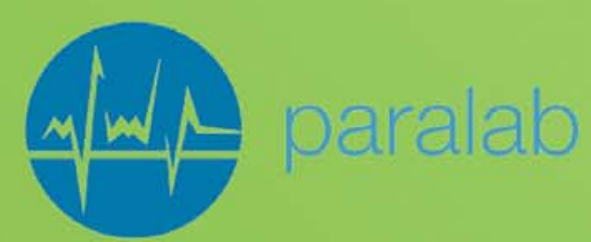

\section{COcean Coptics}

\section{Inovação em Espectroscopia}

Incluindo 3 anos de garantia em todos os espectrometros
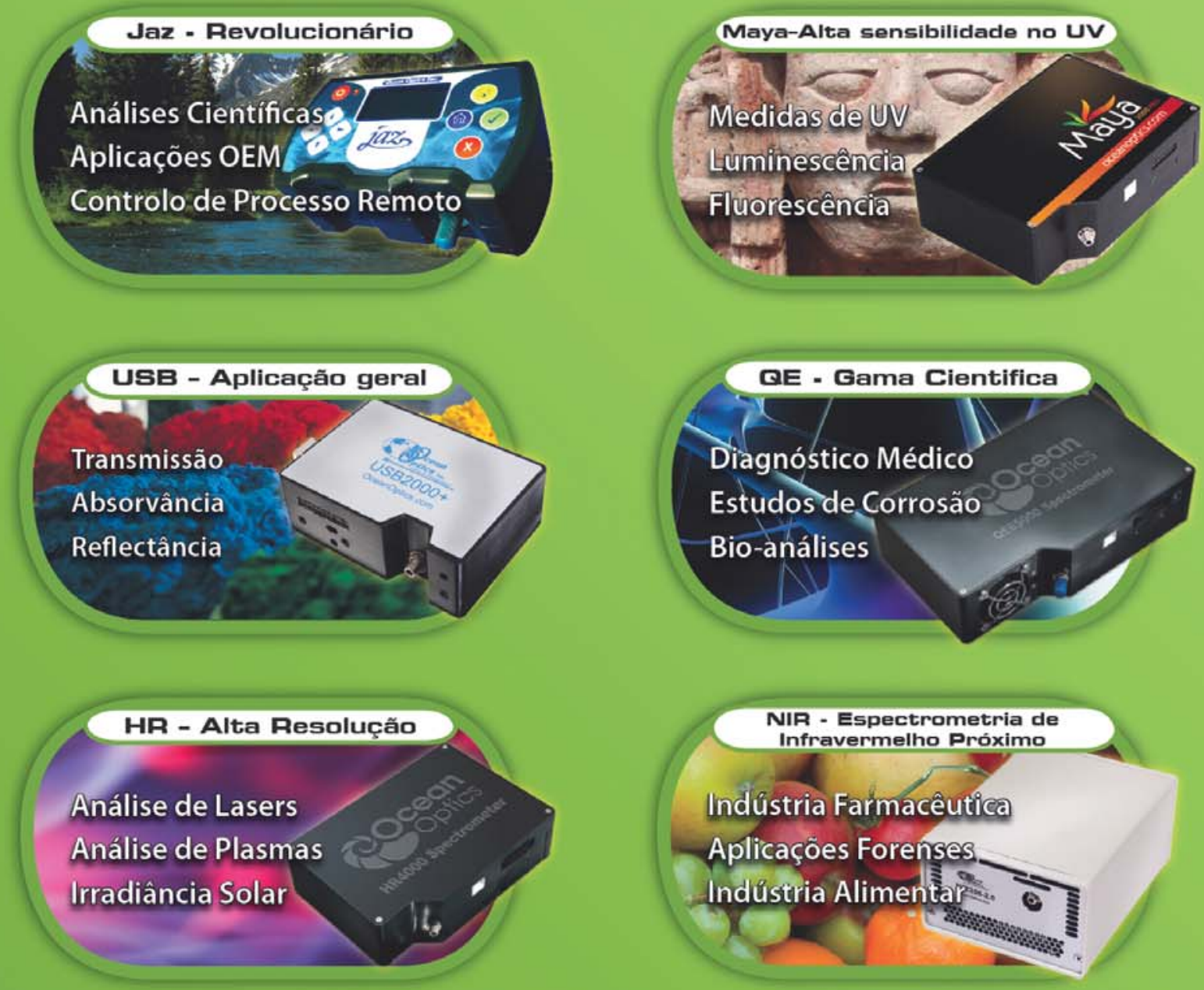

\section{Ligue-nos para o 224664320 para todas suas necessidades de detecção ópticas} PARALAB | info@paralab.pt | www.paralab.pt 